\title{
Distribution, Sorption and Desorption of Tylosin, Chlortetracycline and their Metabolites in Pig Manure
}

\author{
SINGH Ashok. K. \\ Department of veterinary Population Medicine \\ College of Veterinary Medicine \\ University of Minnesota, St Paul Campus \\ St Paul, MN 55108 \\ Cell phone: 7632349655
}

Received: October 9, 2016 Accepted: October 21, 2016 Published: October 31, 2016

doi:10.5296/jas.v4i4.10128

URL: http://dx.doi.org/10.5296/jas.v4i4.10128

\begin{abstract}
Effects of $\mathrm{pH}$ on sorption, desorption and hysteresis of chlortetracycline (CTCs), tylosin (TYL) and their metabolites have been studied in pig manure samples collected from different pig farms. Approximately $36 \%$ of the samples analyzed tested positive (concentration > quantitative detection limit) for the antibiotics and metabolite residues. The degree of contamination depended upon the manure's $\mathrm{pH}$. The acidic TYL-positive manure samples contained TYL-A and TYL-B, while the basic TYL-positive samples contained TYL-A, TYL-ALD and TYL-D. The CTC-positive manure samples contained mostly CTC, ECTC and ACTC at acidic pH, but mostly CTC, ICTC, EICTC and EACTC at basic pH. For acidic and neutral manure samples, the $\log \mathrm{K}_{\mathrm{D}}{ }^{\text {des }}$ values were greater than the $\log \mathrm{K}_{\mathrm{D}}{ }^{\mathrm{s}}$ values for TYL-B, TYL-A, TYL-ALD, CTC, ACTC, ECTC and EACTC, indicating sorption-desorption hysteresis. TYL-D, ICTC and EICTC did not exhibit sorption-desorption hysteresis. At acidic and neutral $\mathrm{pH}$, the residues remained solid-bound, but an increase in $\mathrm{pH}$ decreased hysteresis, resulting in greater leaching and contamination of the environment. Thus, environmental $\mathrm{pH}$ may determine the antibiotics and metabolite leaching in freshwater at or away from the site of production. In addition, analysis of the parent antibiotic residues may not provide an accurate assessment of the environmental health.
\end{abstract}

Keywords: Chlortetracycline, tylosin, manure, sorption, desorption, hysteresis

\section{Introduction}

CTC (broad-spectrum antibiotics) and TYL (a macrolide antibiotic isolated from a strain of 
Streptomycets fradiae) are fed to the animals in feedlot operations for growth promotion and health maintenance (Pan et al. 2011, Hoese et al. 2009, APHIS 2006, Dewey et al. 1999, Powers 1999, Raman et al. 2004, Kerr et al. 2006). The antibiotics residues could contaminate the terrestrial compartment of the environment by either direct runoff or application of soil with contaminated manure. Pigs excrete a significant fraction of the ingested antibiotics in feces and urine (Elmund et al. 1971, Feinman and Matheson 1978, Alcock et al. 1999, Kolz et al. 2005). Earlier studies have reported the CTC and TYL concentrations in pig manure samples collected from different swine facilities in the United States, Europe and Asia ranged from $100 \mu \mathrm{g} / \mathrm{Kg}$ (solid) or L (liquid) to greater than 700,000 $\mu \mathrm{g} / \mathrm{Kg}$ or L (Martinez- Carballo et al. 2007, Kumar et al. 2004, Hamscher et al. 2002, Jacobsen and Halling-Sørensen 2006, Karci and Balcioglu 2009, Zhang et al. 2005, Liu et al. 2009, Wei et al. 2009, Winckler et al. 2003, Hu et al 2008). The issue of antibiotic contamination is compounded by the fact that approximately $39 \%$ of all livestock in the U.S. are grown in confinement where they produce an estimated 175 million tons of manure (Kowalski et al. 2013, Lens et al. 2004) that are applied to the soil as an alternative to chemical fertilizer. Therefore, if manure is contaminated, it may also contaminate the applied fields due to leaching of the pollutants (Dolliver et al. 2007). The occurrence of antibiotics in the environment may be causally related to an increase in bacterial resistance in manure and waste effluent (Halling-Sorensen et al. 1998, Levy 1998, Goni-Urriza et al. 2000, Ogan and Nwiika 1993). Therefore, presence of antibiotic residues in the environment may pose a serious public health concern (Klaver and Matthews 1994, Halling-Sorensen 2001, Chee-Sanford et al. 2001, Boxall et al. 2003) that must be addressed. But, there is limited information on fate of antibiotics in animal manure since earlier studies have studied the fate of antibiotics in clays, organo-clays, humic materials and other soil types (Sassman and Lee 2005, Porubcan et al. 1978, Sithole and Guy 1987, Kay et al. 2004, 2005, Kin et al. 2011).

The main processes potentially affecting the distribution and fate of antibiotics in manure and soil are (i) their sorption to and desorption from manure or soil, (ii) chemical/biological transformations and (iii) transport through soil and water channels (Saltzman and Yaron 1986; van der Hoff and van Zoonen 1999). Sorption and desorption processes of a chemical depend upon the physicochemical properties of pollutants and chemical composition of manure determined by the differences in animal food sources and size of the operation (Kowalski et al. 2013). The solid fraction of manure contains (i) a mixture of soil, organic matter, enzymes that degrade chemicals, humus, and nutrients, (ii) anionic groups such as $-\mathrm{CO}_{2}^{-}$and $-\mathrm{O}^{-}$ groups that attract cations such as $\mathrm{Ca}^{2+}, \mathrm{Mg}^{2+}$, and $\mathrm{Al}^{3+}$ and (iii) hydrophobic groups that retains hydrophobic chemicals (Brady 1974, Sanchez and Gonzalez 2005). Antibiotics may bind the soil particles by either replacing the cations, a process known as cation-exchange or binding via hydrophobic interaction (Sassman and Lee 2005). The observations that free antibiotics present in manure is taken up by plants that accumulate the antibiotics in stem, leaves and fruits (Kang et al. 2013, Dolliver et al. 2007, Kumar et al. 2005, Krebs et al. 1998) suggests that consumers may unknowingly be ingesting some of the antibiotics when they eat vegetables grown on manure-applied lands. However, substantial evidence support that, in addition to the parent antibiotics, their metabolites and some secondary metabolites exhibit may also exhibit biological activities (Habbu et al. 2016, Berdy 2005, 1995, 1989,1985, 


\section{Macrothink}

Donadio et al. 2002, Omura 1992, Demain 1999, Sassman and Lee 2005, Halling-Horensen et al. 2002, McCormick et al. 1957). Thus, in addition to CTC and TYL-A, their metabolites may also pose significant health risk to exposed humans and animals. Unfortunately, the fate of antibiotics metabolites in animal manure is not fully understood.

Therefore, the overall aim of the present investigation was to study the occurrence, sorption and desorption of TYL, CTC and their metabolites in manure samples obtained from pig farms. The hypotheses are that (i) the ionic and hydrophobic properties of CTC, TYL and their metabolites play a critical role in their binding to manure solids and (ii) TC and TYL metabolites are poorly retained by manure solids, exhibiting greater mobility (Figure-1).

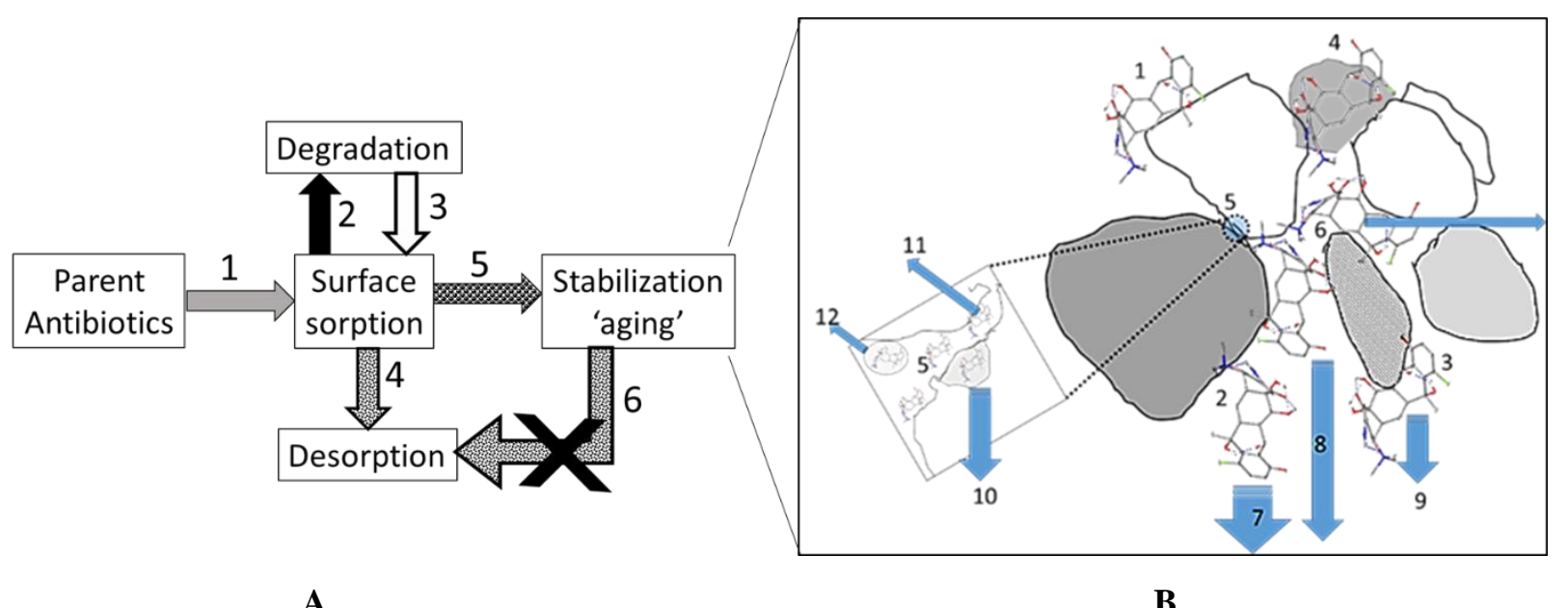

A

B

Figure-1. The environmental fate of TYL, CTC and their metabolites in pig manure.

The Fate of antibiotics in manure is determined by their sorption to the manure-solid surface (Figure 1A-1) followed by their (i) desorption and migration (Figure 1A-4), (ii) 'aging' or stabilization (Figure 1A-6 and Figure 1B) and ensuing decrease in desorption, a process known as hysteresis (HYS), and (iii) biodegradation that results in formation of metabolites (Figure 1A-2) that may distribute between manure's liquid and solid (Figure 1A-3). Abbreviations for Figure 1B: 1 and 2 represent selective polar binding, 3 represents non-polar (hydrophobic) binding, 4 and 12 represents bacterial or root internalization and metabolism, 5 and 11 are chemical binding and stabilization (causing hysteresis), 6 is pore internalization, 7 to10 are desorption.

\section{Materials and Methods}

\subsection{Chemicals and Supplies}

TYL, CTC and metabolites were purchased from Sigma Chemicals Co. (St Louis, MO). The CTC metabolites were Iso-CTC hydrochloride (ICTC), anhydro-CTC hydrochloride (ACTC)), 4-epi-CTC hydrochloride (ECTC), and 4-epi-anhydro-CTC hydrochloride (EACTC). The column used for chromatographic separation of these antibiotics was $150 \mathrm{x}$ $4.6 \mathrm{~mm}$, Adsorbosphere-ODS, $5 \mu, \mathrm{C}_{18}$ column (Alltech, CA). The manure samples were collected from farms (at least 1500 growing and finishing pigs) in Minnesota, Iowa, North 
Dakota and North Carolina.

\subsection{Physicochemical Properties of the Antibiotics and their Metabolites}

The 2D structures of TYL-A, TYL-B, TYL-C, and TYL-D, OMT, DMT, CTC $(+-0,0-0$ and + - - (Stephens et al., 1956), ECTC, ICTC, EICTC and EACTC (protonated and deprotonated) were drawn using ChemDraw. The 2D structures were imported to the ChemDraw 3D and MOE software and minimized to the minimum energy conformation before calculating their physicochemical, electronic and topological properties.

\subsection{Processing and Properties of Manure Samples}

\subsubsection{Manure Processing}

Whole manure samples were collected from pig farms and handled as described previously (Singh et al. 2013, Singh 2015, 2016). Immediately after collection, each sample was mixed with internal standards to track possible degradation and then split in two parts.

- Part-1 (30\% by weight) samples were thawed and autoclaved as described previously (Lesan and Bhandari 2003) to prevent antibiotic degradation during processing. The samples were screened for CTC, TYL and their and metabolites (using the HPLC method described below) to identify antibiotic-positive (antibiotic and metabolite concentrations greater than the method's minimal detection limit (MDL)) and antibiotic-negative (antibiotic and metabolite concentrations less than the method's MDL) manure samples. The screening showed that about $30 \%$ of the analyzed samples tested positive for CTC, TYL and their metabolite residues.

- Part-2 (70\% by weight) samples were thawed, sterilized and analyzed for antibiotic concentrations in liquid and solid fractions. The solid-water distribution and desorption of antibiotics were measured using isotherm equations described later.

All samples were analyzed for total organic carbon (OC), total wet manure solid (TS) and total Kjeldahl nitrogen (TKN) concentrations.

\subsubsection{Manure Characterization}

Total Organic Carbon was measured using a procedure described by Perrier and Kellogg (1960). Total Wet Manure Solid (TS) and Total Kjeldahl nitrogen (TKN) was determined using procedures described in a University of Wisconsin Madison Extension Publication A3769 (Peters 2003). Cation Exchange Capacity was measured using $\mathrm{BaCl}_{2}$ and triethanolamine as described by Lax et al (1980). During the method validation phase, the $\mathrm{BaCl}_{2}$ method was compared with the ammonium acetate method described by Sumner and Miller (1996).

\subsubsection{Screening of Manure for CTC, TYL and their Metabolites}

\subsubsection{Extraction of antibiotics and metabolites from manure samples}

Each manure sample was centrifuged and the solid and liquid phases were collected. The liquid samples were mixed with internal standards (demeclocycline (DMCTC) for CTC and 
roxithromycin (Ro) for tylosin) and concentrated to $10 \mathrm{ml}$ using a freeze drier. The dried samples were stored at $-80^{\circ} \mathrm{C}$ for further analysis. The solid samples were washed with pure water $(\mathrm{x} 10 \mathrm{w} / \mathrm{v})$ followed by $\mathrm{CaCl}_{2}$ solution $(0.5 \mathrm{M})(\mathrm{x} 5 \mathrm{w} / \mathrm{v})$ for elution of the antibiotics and the metabolites. Each pooled eluates were freeze dried and stored at $-70^{\circ} \mathrm{C}$ for further analysis.

\subsubsection{Extraction of CTC and Metabolites (Zhu et al 2001)}

Manure samples (liquid or solid eluate) containing CTC and its metabolites were mixed with $10 \mathrm{ml}$ of phosphate buffer $(0.05 \mathrm{M}$ sodium phosphate mono-basic, $0.05 \mathrm{M}$ citric acid, $\mathrm{pH} 4$, $0.05 \mathrm{M}$ EDTA). The samples were mixed thoroughly and centrifuged. Clear supernatant was mixed with $20 \mathrm{ml}$ of reagent water that was poured onto a $\mathrm{C}_{18}$ column (500 mg, BOND ELUT, Varian, Harbor City, CA) conditioned with $10 \mathrm{ml}$ methanol and $10 \mathrm{ml}$ water. The column was prevented from drying completely after the entire samples had passed through it (the column efflux was retained for re-extraction). The bound-antibiotics were eluted with 2 $\mathrm{ml}$ of methanolic oxalic acid $(0.01 \mathrm{M})$ followed by acetonitrile. The eluates were pooled and concentrated to $0.1 \mathrm{ml}$, then analyzed directly.

\subsubsection{Extraction of Tylosin and Metabolites (Nozal-Nalda et al 2006)}

Polymeric sorbent SPE tubes (6 mL with $200 \mathrm{mg}$ of sorbent, Strata X-331m) conditioned with methanol and water $(5 \mathrm{ml})$ were used. The $\mathrm{pH}$ of each concentrated extract was adjusted to 9 with carbonate buffer (100 mM, pH 9) and loaded on an conditioned SPE polymeric cartridge at about $1 \mathrm{~mL} / \mathrm{min}$ using a suction system. Then, the columns were washed with $4 \mathrm{~mL}$ of 70:30 v/v water/ methanol (this rinse was stored for re-extraction is necessary). The analytes were eluted with $1 \mathrm{~mL}$ of methanol followed by $1 \mathrm{~mL}$ of acetonitrile.

2.3.3.4. Chromatography - CTC and Metabolites: The MS system used was Applied Biosystems API 3000 (Applied Biosystems, Foster City, CA, USA) equipped with an electrospray source. Coupled to a Waters 2690 Alliance system (Milford, MA, USA) equipped with a tertiary gradient system. The columns and elution buffers used has been described previously (Soeborg et al. 2004). The separation was performed using the following mobile buffers: A - $200 \mathrm{ml}$ methanol, $310 \mu \mathrm{l}$ formic acid and milliQ water up to $1 \mathrm{~L}$; and B- $950 \mathrm{ml}$ methanol, $310 \mu \mathrm{l}$ formic acid and milliQ water up to 1L. A procedure described by Tylova et al. 2013 and Soeborg et al. (2004) was used in this study. The MS analysis was performed in the positive ion mode using the settings described previously (Soeborg et al 2004). Product ions were m/z 461>444 for ACTC and EACTC, 479>444 for CTC, 479>462 for ICTC and 427>410 for EATC.

\subsubsection{Chromatography - Tylosin and Metabolites}

The procedure described by Nozal-Nalda et al. (2006) was modified to determine concentrations of TYL and its metabolites in manure liquid and solid samples. In brief, the analytes were separated a C18 column using formic acid $1 \%$ in water (solvent $\mathrm{A}$ ), methanol (solvent $\mathrm{B}$ ) and $\mathrm{ACN}$ (solvent $\mathrm{C}$ as mobile phase at a flow rate of $0.8 \mathrm{~mL} / \mathrm{min}$. A. The tertiary programming was modified for clear separation: $0 \mathrm{~min}$ 70/60/0 (A/B/C), $10 \mathrm{~min}$ 60/40/0, 20 $\min 70 / 5 / 25,25 \min 70 / 0 / 30$ and $35 \mathrm{~min} 60 / 40 / 0$ (equilibration for $5 \mathrm{~min}$ ). 


\section{$\Lambda$ Macrothink}

For quantification, a stock standard solutions for CTC, TYL-A and metabolites were prepared in water-methanol (70:30) or pure methanol at a concentration of $200 \mathrm{mg} / \mathrm{L}$. A set of working standards ( 0 to $5 \mathrm{mg} / \mathrm{ml}$ ) containing $(1 \mathrm{mg} / \mathrm{ml})$ roxithromycin (internal standard) were prepared using analyte-free manure liquid or solid eluates. All working standards were stored at $4^{\circ} \mathrm{C}$ and prepared fresh daily. The calibration samples were analyzed with each batch of analytes and a calibration curve was plotted using response (peak area or ion $(\mathrm{m} / \mathrm{z})$ intensity) on $\mathrm{y}$-axis and concentration on $\mathrm{x}$-axis. Manure analytes were determined using linear regression. At least three levels of the QAQC samples were used to ensure concentration accuracy.

\subsection{Sorption, desorption and hysteresis of CTC, TYL-A and metabolites}

\subsubsection{Sorption coefficient $\left(\log \mathrm{K}_{\mathrm{D}}^{\mathrm{s}}\right)$ :}

The antibiotic and metabolite concentration in solid and liquid fractions were fitted to equation-1 to calculate $\log \mathrm{K}_{\mathrm{D}}{ }^{\mathrm{s}}$ values.

$$
\log K_{D}^{S}\left(L . K g^{-1}\right)=\log \left[\frac{A_{e}(\%)}{100-A_{e}(\%)}\left[\frac{V_{0}}{m_{\text {solid }}}\right]\right] \quad \text { Equation } 1
$$

In equation- $1, \mathrm{~A}_{\mathrm{e}}$ is $\%$ adsorption, $\mathrm{V}_{0}$ is initial volume, and $\mathrm{m}_{\text {solid }}$ is total solid mass. An increase in $\log \mathrm{K}_{\mathrm{D}}{ }^{\mathrm{s}}$ is associated with a decrease in the leaching capacity of the compound (Sanchez-Camazano et al. 1994).

\subsubsection{Desorption}

Manure solids (pre-analyzed for TYL-A, CTC and metabolite concentrations) were centrifuged and the supernatant was completely aspirated. The liquid volume was recorded for each sample. The solid fraction was mixed with an antibiotic-free phosphate buffer, $\mathrm{pH} 6,7,8$ or 9, mixed with $0.02 \mathrm{M} \mathrm{CaCl}_{2}$ solution (the volume of the buffer was equal to the sample's original liquid volume), mixed thoroughly, equilibrated for $24 \mathrm{~h}$ at room temperature and centrifuged at $3000 \times g$ for $20 \mathrm{~min}$. Then, $5 \mathrm{ml}$ aliquot was removed from the supernatant and immediately replaced by equal volume of fresh desorption solution. Desorption step was repeated four times (Figure 2).

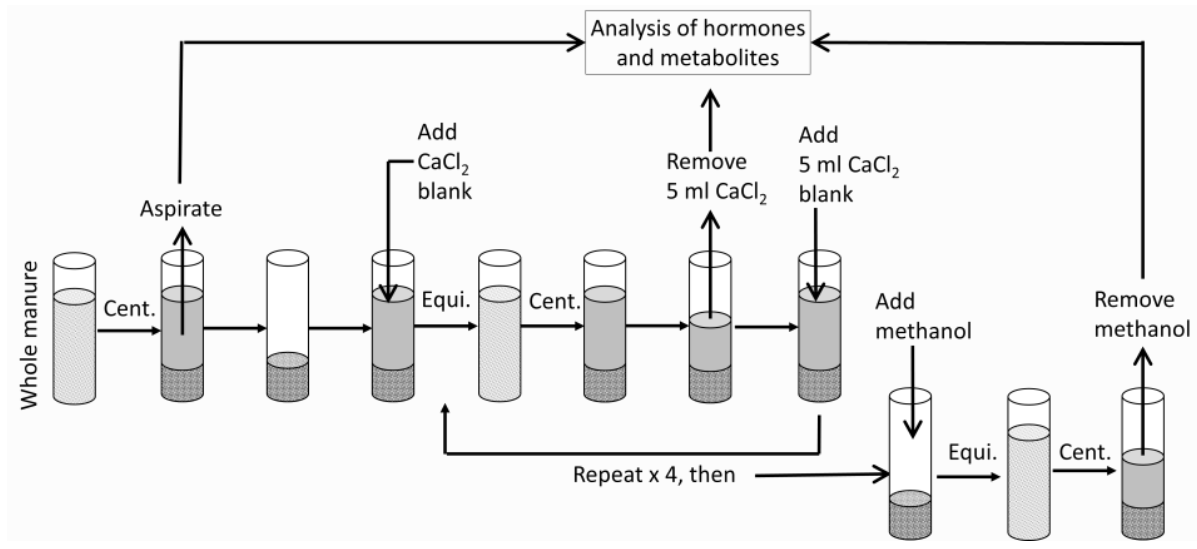


Figure2. The antibiotics desorption procedure used in this study.

Finally, the residues remaining in the solid were extracted with methanol. The supernatants were evaporated over nitrogen almost to dryness. A final volume of $1 \mathrm{~mL}$ was reconstituted in acetonitrile to be analyzed by HPLC/UV/MS-MS to determine the antibiotic concentrations in the equilibrium solution. Blank controls (solution + test substance without soil/sediment) were subject to the same test procedures to assess potential sorption to glass test vessels and potential of loss due to chemical hydrolysis. One $\mathrm{ml}$ of the blank buffer was removed and analyzed using HPLC/UV/MS-MS. The remaining solution was mixed with one $\mathrm{ml}$ of blank (antibiotic free $\mathrm{CaCl}_{2}$ ) solution, incubated and analyzed. This was repeated four times, aqueous desorption steps 1 to 4 . This was followed by a methanol desorption. The results were used to calculate $\log \mathrm{K}_{\mathrm{D}}{ }^{\text {des }}$ using equation-2 (USEPA OECD/OCDE \#106, 2004).

$$
\log K_{D}^{\text {des }}=\log \left[\frac{m_{s}^{a d}(e q)}{m_{a q}^{d e s}(e q)} \frac{V_{T}}{m_{\text {solid }}}\right]\left(\mathrm{L}_{\mathrm{K}} \mathrm{Kg}^{-1}\right)
$$

Equation-2

In equation $2, \mathrm{~m}_{\text {solid }}$ is quantity of the soil phase (dry mass, $(\mathrm{g})$ ), $\mathrm{m}_{\mathrm{aq}}{ }^{\text {des }}$ (eq) is mass of the antibiotics or metabolites in the aqueous phase at desorption equilibrium $(\mu \mathrm{g}), \mathrm{m}_{\mathrm{s}}$ ad is mass of the test substance remaining in the soil phase at desorption equilibrium $(\mu \mathrm{g})$ and $\mathrm{V}_{\mathrm{T}}$ is total volume of the aqueous phase in contact with the soil during the desorption $\left(\mathrm{cm}^{3}\right)$.

\subsubsection{Hysteresis coefficient (HC)}

$\mathrm{HC}$ was calculated using equation -3. An increase in $\mathrm{HC}$ values represents an increase in sorption-desorption hysteresis.

$$
H C(\%)=\left[\frac{K_{D}^{\text {des }}-K_{D}^{s}}{K_{D}^{\text {des }}}\right] * 100
$$

Equation-3

\subsection{Statistics}

The data were represented as mean \pm standard deviation. SPSS (SPSS Inc. Chicago, IL) was used to determine significance of difference between two means at $\alpha=0.05$.

\section{Results}

\subsection{Manure Characteristics}

Overall manure characteristics are listed in Table-1. The solids content of the manure samples collected in this study varied from $<20 \%$ to $66 \%$. TS, TOC and TKN (\%) values for whole manure were insensitive to $\mathrm{pH}$ differences from 5.5 to $>9$. The CEC values decreased significantly as $\mathrm{pH}$ increased. 
Table-1. Swine manure properties.

\begin{tabular}{|r|l|l|l|l|}
\hline \multicolumn{1}{|l|}{ Indices } & $\mathrm{pH}$ & $\mathrm{pH}$ & $\mathrm{pH}$ & $\mathrm{pH}$ \\
& $5.5-6.5$ & $>6.5-7.5$ & $>7.5-8.5$ & $\geq 9$ \\
\hline TS (\%) & $21 \pm 9$ & $19 \pm 11$ & $27 \pm 11$ & $35 \pm 18$ \\
TOC (\%) & $35 \pm 21$ & $31 \pm 13$ & $23 \pm 10$ & $21 \pm 9$ \\
TKN (g/kg) & $23 \pm 11$ & $26 \pm 9$ & $29 \pm 7$ & $26 \pm 8$ \\
CEC & & $79 \pm 17^{*}$ & $51 \pm 7^{*}$ & $17 \pm 10^{*}$ \\
& & & & \\
\hline
\end{tabular}

Please align Indices with $\mathrm{pH}$ values

TS: total solid, TOC: total organic carbon, TKN: Total kjeldahl nitrogen, and CEC: cation exchange capacity. $* \mathrm{p}<0.05$ significant when compared with acidic manure

\subsection{Physicochemical Properties of Antibiotics}

\subsubsection{Tylosin-A and Metabolites}

Figure-3 shows general structure of TYL and its metabolites. TYL-A, the parent compound contained, is a polyketide lactone substituted with three deoxyhexose sugars mycinose, mycaminose and mycarose. TYL metabolites are generated by loss of different substituted groups. Figure-4 shows the 3D structures of MM2 minimized 3D structures of TYL-A exhibiting distinct hydrophobic and hydrophilic surfaces with sugars in same plane, while the +ve charged $\mathrm{NH}_{3}{ }^{+}$in an opposite plane. Although TYL-A and metabolites common pKa value, TYL-B is most hydrophobic and has least PSA. TYL-ALD was most hydrophilic metabolite. The molecular weight exhibited the following pattern: TYL-A > TYL-B, TYL-D > TYL-ALD. 

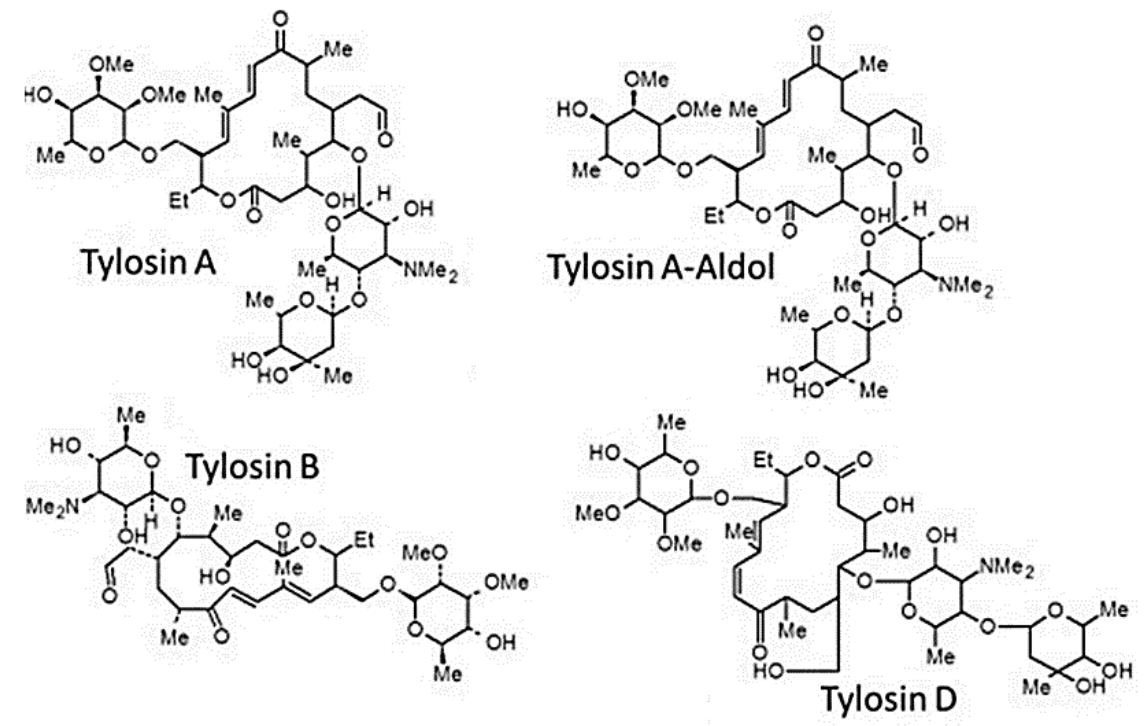

Figure 3. Chemical Structure of TYL-A and metabolites

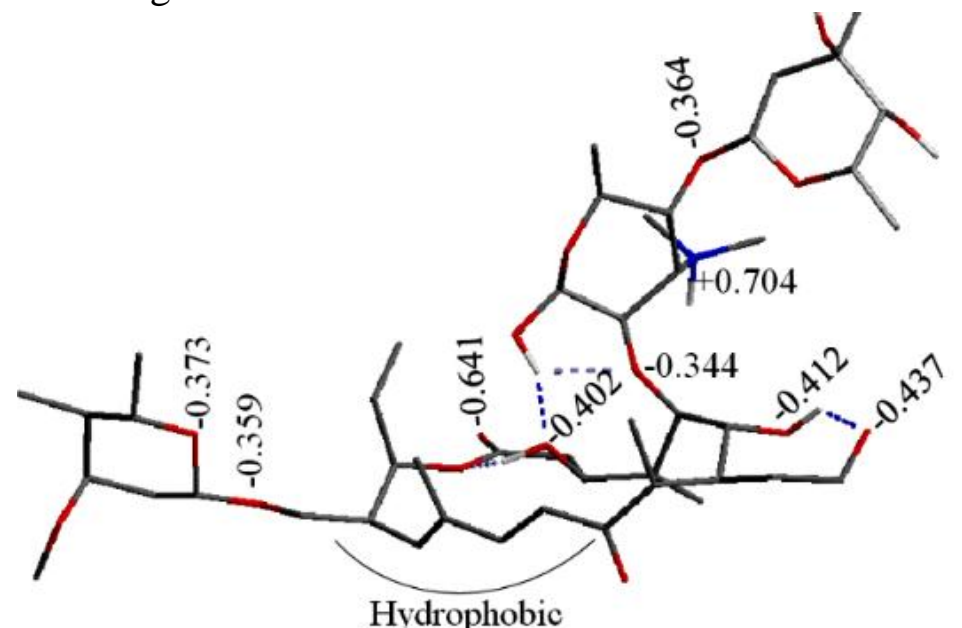

Figure-4: Three Dimensional Structure of TYL-A Showing Its Electronic Charges and Hydrophobic Site.

Table 2. Physicochemical Properties of TYL-A and Its Metabolites.

\begin{tabular}{|l|l|l|l|l|}
\hline Indices & TYL-A & TYL-B & TYL-D & TYL-ALD \\
\hline PSA & 219 & 140 & 238 & 240 \\
\hline pKa & 8.9 & 8.9 & 8.9 & 8.9 \\
\hline Lipinski rule & & & & \\
Molecular weight (Mw) 180 -500 & $900 *$ & $756^{*}$ & $756^{*}$ & $584^{*}$ \\
\# H bond acceptor (HBA) $\leq 10$ & $15^{*}$ & $12^{*}$ & $12^{*}$ & 8 \\
\# H bond donor (HBD) $\leq 5$ & 5 & 4 & 4 & 5 \\
\# rotatable bonds (RB) $\leq 10$ & $13^{*}$ & $11^{*}$ & 11 & 7 \\
LogP $\quad 0.40-5.6$ & 1.66 & 2.3 & 1.7 & 1.3 \\
\hline
\end{tabular}

PSA: polar surface area, pKa: dissociation constant, ${ }^{*}$ Not conforming to the Lipinski rule.

\subsubsection{Chlortetracycline and Metabolites}




\section{Macrothink}

Figure-5 shows 2D structures of CTC metabolites 4-epi-CTC (ECTC), iso-CTC (ICTC), 4-epi-iso-CTC (EICTC), anhydro-CTC (ACTC) and epi-anhydro-CTC (EACTC). In general, CTC is based on the octahydro-naphthacene ring structure having (i) one aromatic (D) and three $(A B C)$ alicyclic alkane rings (Figure 4B), (ii) six oxygen function groups in lower parts and $\mathrm{C}$, (iii) a dimethylamine group at $\mathrm{C} 4$-ring $\mathrm{A}$ and (iv) a $\mathrm{Cl}$ substation at $\mathrm{C} 7$ in ring $\mathrm{D}$ (Figure 6).

CTC

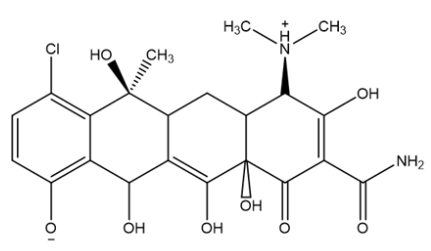

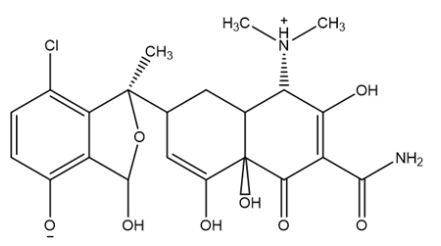

EICTC
ECTC

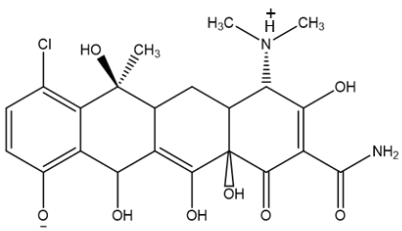

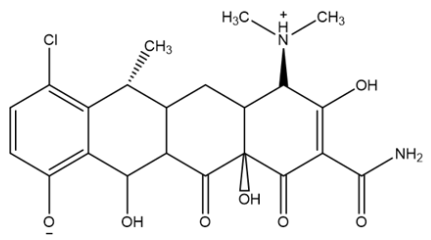

ACTC
ICTC

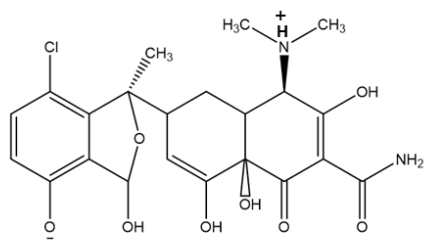

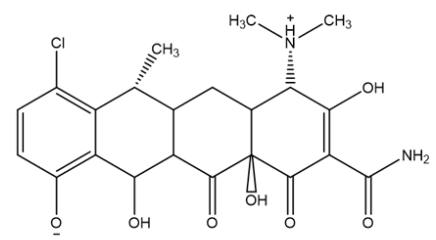

EACTC

Figure 5. Chemical structures of chlortetracycline (CTC) and its metabolites.

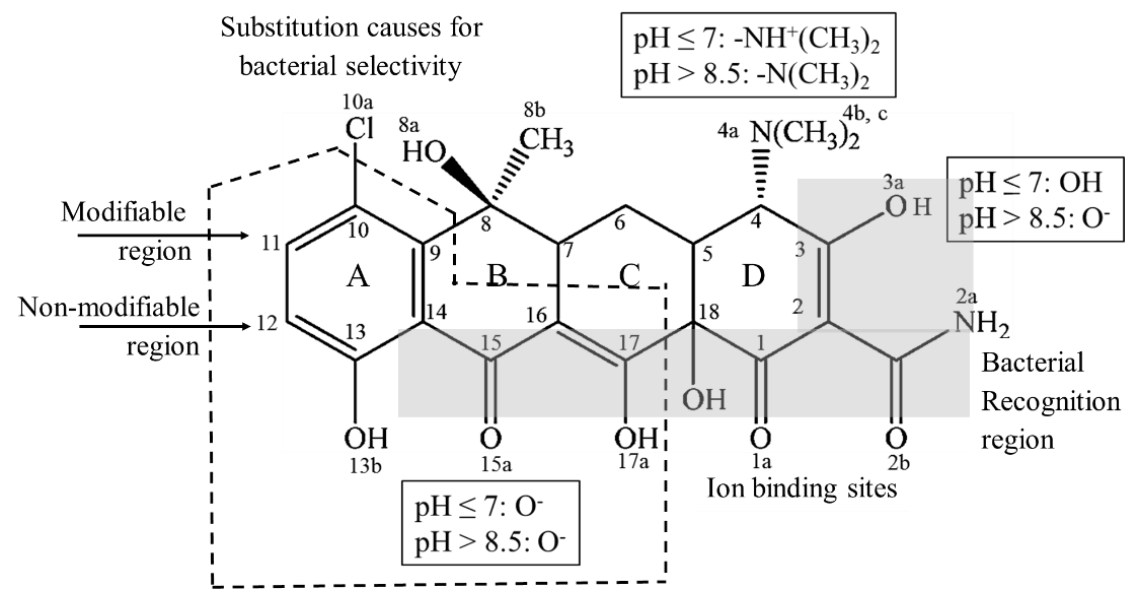

Figure-6. CTC structure-function relationship and ionization characteristics.

Abbreviations: ECTC is epiCTC, ACTC is anhydroCTC, EACTC is epiACTC, ICTC is isoCTC and EICTC is epiICTC.

Table 3 shows the physicochemical properties, while Table 4 lists the electronic properties of CTC and metabolites. The upper region of CTC is known as the modifiable region that can alter its biological properties and selectivity. The antibiotics also exhibits complex ionization patterns (Figure 6). At acidic $\mathrm{pH}$, only the $4 \mathrm{C}$ nitrogen is protonated $\left(-\mathrm{NH}\left(\mathrm{CH}_{3}\right)_{2}{ }^{+}\right)$. At $\mathrm{pH}>9$, the two hydroxyl groups are sequentially deprotonated, resulting in formation of ionized $\mathrm{O}^{-}(\mathrm{O}$ 
$3 \mathrm{a}$ and/or $\mathrm{O} 13 \mathrm{~b}$ ). At $\mathrm{pH}$ ranging from 7 to 8.5, CTC may exist as a zwitterion with net neutral (one $\mathrm{O}^{-}$) or negative (two $\mathrm{O}^{-1}$ ).

Table 3. Physicochemical properties of chlortetracycline and their metabolites.

\begin{tabular}{|c|c|c|c|c|c|c|}
\hline Indices & CTC & ECTC & ICTC & EICTC & ACTC & EACTC \\
\hline PSA & 187 & 188 & 164 & 164 & 164 & 164 \\
\hline pKa1 & 9.3 & 9.3 & 8.4 & 8.4 & 9.4 & 9.4 \\
\hline pKa2 & 7.4 & 7.4 & 6.4 & 6.4 & 7.4 & 7.4 \\
\hline pKa3 & 4 & 4 & 3.6 & 3.6 & 4 & 4 \\
\hline Lipinski rule & \multirow{7}{*}{$\begin{array}{l}479 \\
9 \\
-5 \\
-3 \\
-3.3\end{array}$} & \multirow{7}{*}{$\begin{array}{l}480 \\
8 \\
7 \\
2 \\
-3.3\end{array}$} & \multirow{7}{*}{$\begin{array}{l}463 \\
8 \\
4 \\
2 \\
-2.17\end{array}$} & \multirow{7}{*}{$\begin{array}{l}479 \\
9 \\
5 \\
2 \\
-2.17\end{array}$} & \multirow{7}{*}{$\begin{array}{l}464 \\
7 \\
5 \\
2 \\
-0.58\end{array}$} & \multirow{7}{*}{$\begin{array}{l}479 \\
9 \\
6 \\
2 \\
-0.58\end{array}$} \\
\hline Molecular weight $(\mathrm{Mw}) 180$ & & & & & & \\
\hline 500 工 & & & & & & \\
\hline$\# \mathrm{H}$ bond acceptor $(\mathrm{HBA}) \leq 10$ & & & & & & \\
\hline \# H bond donor $(\mathrm{HBD}) \leq 5$ & & & & & & \\
\hline \# rotatable bonds (RB) & & & & & & \\
\hline $0.40-5.6$ & & & & & & \\
\hline
\end{tabular}

The electronic charged in selected $\mathrm{N}$ and $\mathrm{O}$ atoms in different ionization forms of CTC is shown in Table 4. The ionized atoms exhibited expected positive and/or negative charge, respectively, for $\mathrm{CTC}^{+00}$ (+ve charge) and $\mathrm{CTC}^{0-0}$ (-ve charge) or $\mathrm{CTC}^{+-}$(-ve charge). At higher $\mathrm{pH}$, the deprotonated $-\mathrm{N}\left(\mathrm{CH}_{3}\right)_{2}$ at $\mathrm{C} 4$ also exhibited electron deficiency with positive charge $>1$, possibly due to electron delocalization. Thus, CTC may behave like a zwitterion even if $-\mathrm{N}\left(\mathrm{CH}_{3}\right)_{2}$ remains deprotonated (Table 4).

Table 4. Electronic charge in $\mathrm{O}$ and $\mathrm{N}$ atoms in different CTC (Figure 6 for atom location).

\begin{tabular}{|c|c|c|c|c|c|}
\hline & 000 & 00 - & $0-0$ & +00 & +-- \\
\hline Atoms & $\begin{array}{c}\text {-OH 3a } \\
\text { Protonated } \\
-\mathrm{N}\left(\mathrm{CH}_{3}\right)_{2} 4 \mathrm{a} \\
\text { Deprotonated }\end{array}$ & $\begin{array}{l}\mathrm{O}^{-} 3 \mathrm{a} \\
\text { Deprotonated } \\
-\mathrm{N}\left(\mathrm{CH}_{3}\right)_{2} \quad 4 \mathrm{a} \\
\text { Deprotonated }\end{array}$ & $\begin{array}{l}\mathrm{O}^{-} 13 \mathrm{~b} \\
\text { Deprotonated } \\
-\mathrm{N}\left(\mathrm{CH}_{3}\right)_{2} \\
\text { Deprotonated }\end{array}$ & $\begin{array}{l}\mathrm{N}\left(\mathrm{CH}_{3}\right)_{2}^{+} 4 \mathrm{a} \\
\text { Protonated } \\
\text { OH 3a 13b } \\
\text { Protonated }\end{array}$ & $\begin{array}{c}\mathrm{O}^{-} \quad 3 \mathrm{a} 13 \mathrm{~b} \\
\text { Deprotonated } \\
\mathrm{NH}\left(\mathrm{CH}_{3}\right)_{2}^{+} 4 \mathrm{a} \\
\text { Protonated }\end{array}$ \\
\hline $\mathrm{O} 8 \mathrm{a}$ & -0.32 & -0.291 & -1.025 & -0.31 & -1.069 \\
\hline $\mathrm{O} 13 \mathrm{~b}$ & -0.38 & -0.38 & -0.41 & -0.373 & -0.333 \\
\hline O 15a & -0.518 & -0.528 & -0.531 & -0.513 & -0.573 \\
\hline O 17a & -0.338 & -0.341 & -0.371 & -0.329 & -0.313 \\
\hline $\mathrm{O} 1 \mathrm{a}$ & -0.689 & -0.619 & -6.72 & -0.632 & -0.629 \\
\hline O 3a & -0.148 & -0.702 & -0.151 & -0.121 & -0.732 \\
\hline $\mathrm{N} 2 \mathrm{a}$ & 0.09 & 0.05 & 0.07 & 0.05 & 0.07 \\
\hline $\mathrm{O} 2 \mathrm{~b}$ & -0.825 & -0.844 & -0.867 & -0.844 & -0.813 \\
\hline $\mathrm{N} 4 \mathrm{a}$ & -0.143 & $1.141^{*}$ & $1.157^{*}$ & 0.716 & 0.923 \\
\hline
\end{tabular}




\section{MInstitute Macrothink $_{\text {Int }}$}

The HPLC method used in this study provided clear separation of TYL, CTC and their metabolites from manure samples (Figure 7). The non-quantitative detection limit (nQDL) of the method was $1 \mu \mathrm{g} / \mathrm{L}$, but the quantitative detection limit (QDL) of the method was $20 \mu \mathrm{g} / \mathrm{L}$ when the samples were extracted using $\mathrm{C}_{18}$-column extraction procedure. The recovery of the antibiotics and their metabolites ranged from $80 \%$ to $97 \%$. Approximately $45 \%$ of the analyzed samples tested positive for CTC, TYL-A and their metabolites, but only $36 \%$ of the positive samples contained the residues at concentrations $\geq$ QDL that were further subjected to quantitative analysis. As shown in Figure-8, the liquid antibiotics concentrations negatively correlated with the samples' $\mathrm{pH}$ values: acidic manure samples contained highest concentration of the antibiotic and metabolites that decreased gradually as $\mathrm{pH}$ increased. The acidic TYL-positive manure samples contained mostly TYL-A and TYL-B, while the basic TYL-positive samples contained TYL-A, TYL-ALD and TYL-D (Figure 8). The aqueous phase TYL-A and metabolite concentrations ranged from 1 to $200 \mu \mathrm{g} / \mathrm{L}$. The CTC-positive manure samples contained mostly CTC, ECTC and ACTC at acidic pH, but mostly CTC, ICTC, EICTC and EACTC at basic $\mathrm{pH}$. The aqueous phase CTC and metabolite concentrations ranged from $<1$ to $700 \mu \mathrm{g} / \mathrm{L}$ (Figure 8).
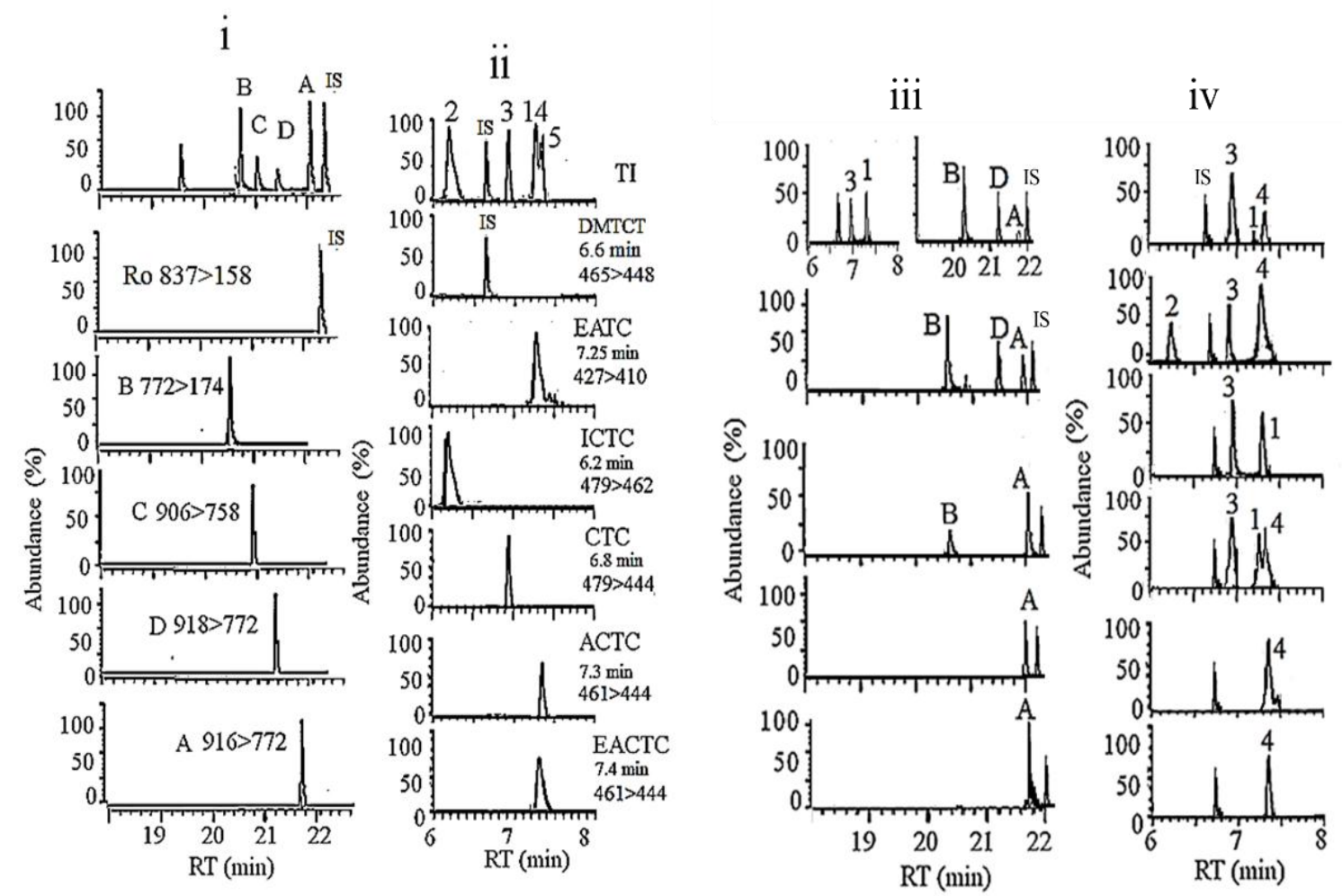

Figure 7. Typical chromatographic separation antibiotic residues.

(i) Separation of TYL-A and metabolites standards. The primary and secondary ions are shown for each analyte,

(ii) CTC and metabolites standard,

(iii) TYL-A and metabolites extracted from manure (iii top: this sample contained TYL and CTC both), and 
(iv) (iv) CTC and metabolites extracted from manure.

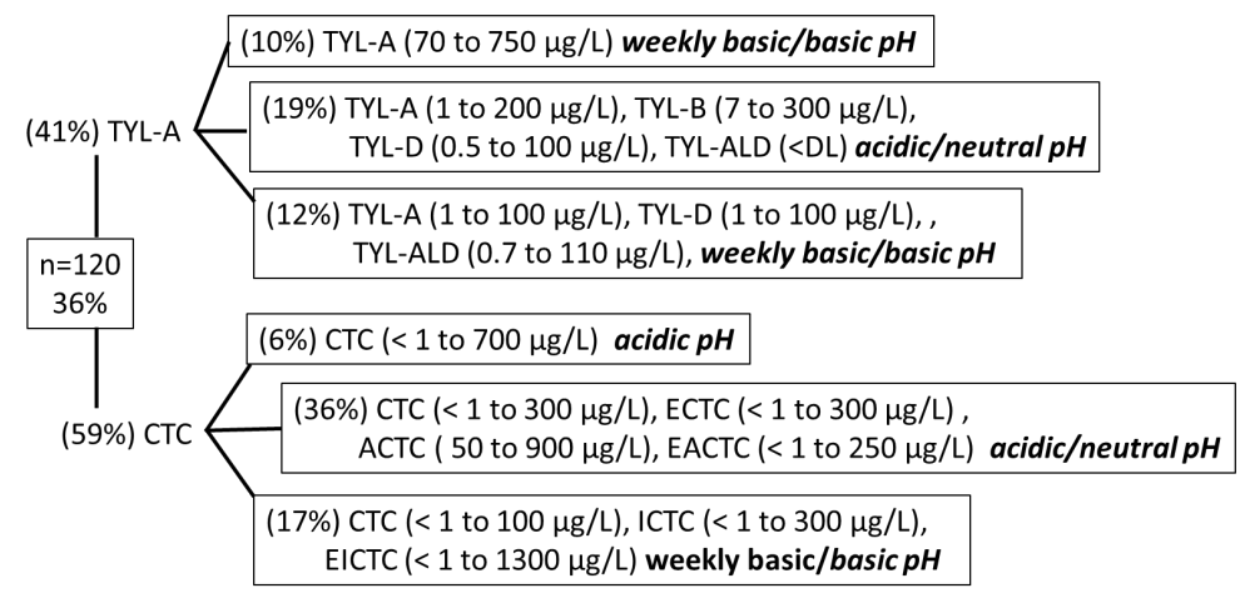

Figure 8. Concentration of TYL-A, CTC and their metabolites in manure liquid samples at different $\mathrm{pH}$ values.

\subsection{Sorption and Desorption Coefficients}

\subsubsection{Chlortetracycline and Metabolites}

Figures-9i show plots of $\mathrm{pH}$ versus $\log \mathrm{K}_{\mathrm{D}}{ }^{\text {des }}$ and $\log \mathrm{K}_{\mathrm{D}}{ }^{\mathrm{s}}$ values and Figure 9ii shows the HYS values for CTC, ACTC and ICTC (values for epimers are not shown to avoid duplication), while the results of their statistical analysis (data from acidic (5.5 to 6.5), neutral (>6.5 to 7.5), slightly basic (>7.5 to 8.5) and basic ( $\geq 9)$ manure samples) are shown in Figure-10. As shown in Table-5, $\log \mathrm{K}_{\mathrm{D}}{ }^{\mathrm{s}}, \log \mathrm{K}_{\mathrm{D}}{ }^{\text {des }}$ and $\mathrm{HC}$ values for CTC and metabolites in acidic, neutral, weakly basic and basic manure samples exhibited different patterns. For CTC, ECTC, ACTC and EACTC, the $\log \mathrm{K}_{\mathrm{D}}{ }^{\text {des }}$ values were higher than the $\log \mathrm{K}_{\mathrm{D}}{ }^{\mathrm{s}}$ values in acidic and neutral manure samples, indicating sorption-desorption hysteresis. For ICTC and EICTC, $\log \mathrm{K}_{\mathrm{D}}{ }^{\mathrm{s}}$ and $\log \mathrm{K}_{\mathrm{D}}{ }^{\text {des }}$ values were comparable, indicating lack of hysteresis. Epimerization did not affect the $\log \mathrm{K}_{\mathrm{D}}^{\mathrm{s}}, \log \mathrm{K}_{\mathrm{D}}{ }^{\text {des }}$ and $\mathrm{HC}$ values of CTC and metabolites in manure samples.
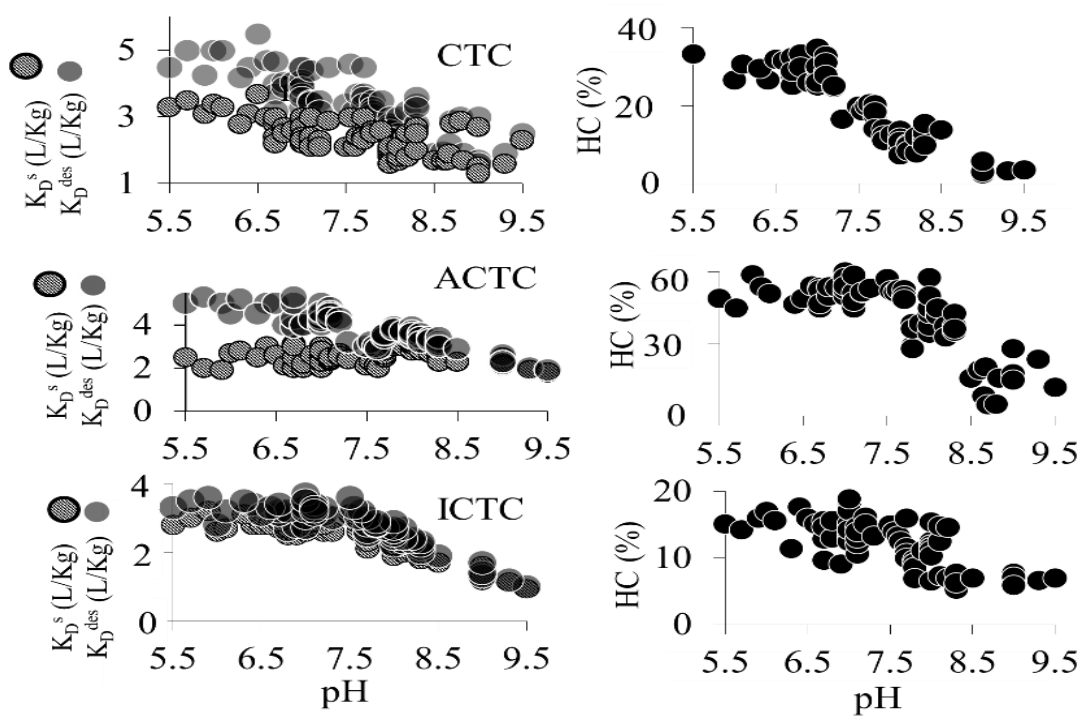


\section{MInstitute Macrothink $_{\text {Int }}^{\text {Intis }}$}

Journal of Agricultural Studies

ISSN 2166-0379

2016, Vol. 4, No. 4

Figure 9. $\operatorname{LogK}_{\mathrm{D}}{ }^{\mathrm{s}}$ or $\log \mathrm{K}_{\mathrm{D}}{ }^{\text {des }} \mathrm{vs} \mathrm{pH}$ (i) and $\mathrm{pH}$ versus HYS (ii) plots for CTC, ACTC and ICTC in manure samples. The data for epimers were not shown since epimerization did not affect the respective values.

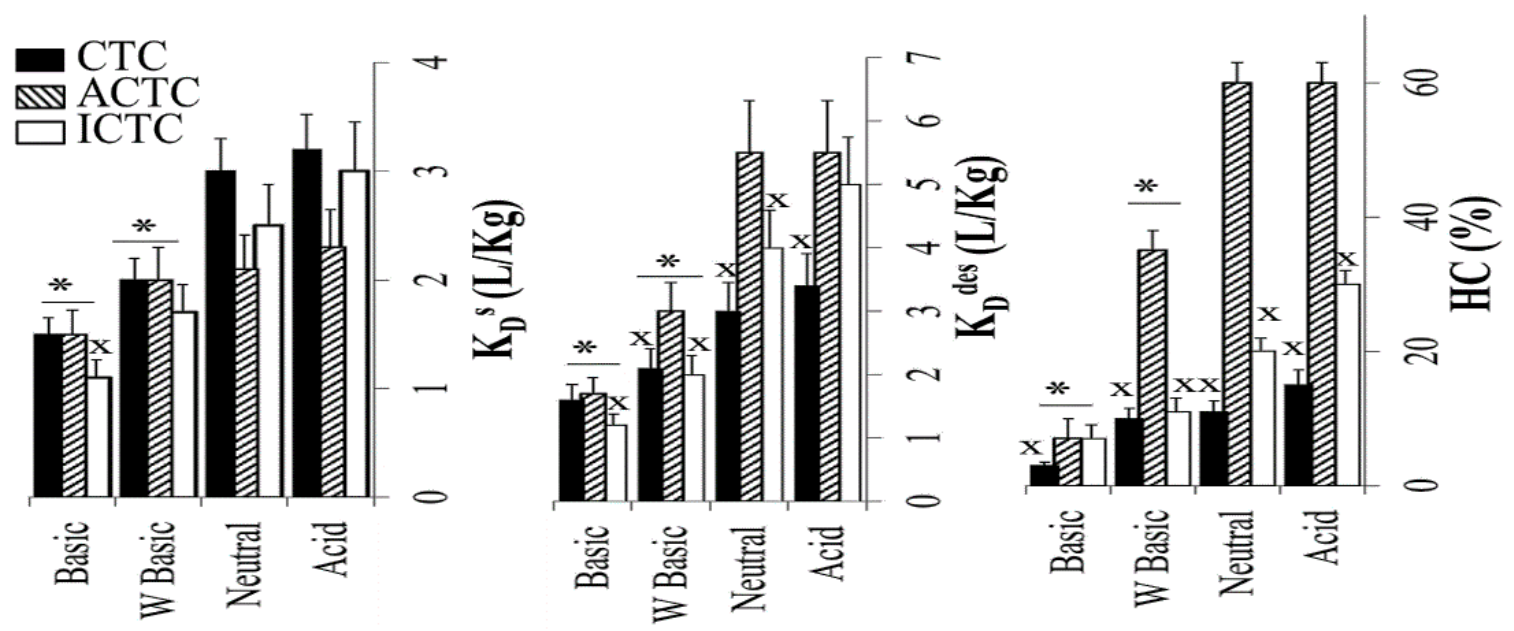

Figure-10. $\log \mathrm{K}_{\mathrm{D}}^{\mathrm{s}}, \log \mathrm{K}_{\mathrm{D}}{ }^{\text {des }}$ and HC values for CTC, ACTC and ICTC in acidic, neutral, weakly $(\mathrm{W})$ basic and basic manure samples.*: significant when compared with the acid-manure values and $\mathrm{x}$ : significant when compared with corresponding ACTC values.

Table5. Effect of manure $\mathrm{pH}$ on sorption, desorption and hysteresis of CTC and metabolites.

\begin{tabular}{|c|c|}
\hline $\begin{array}{l}\text { Sensitivity of } \log \mathrm{K}_{\mathrm{D}}^{\mathrm{s}}, \log \mathrm{K}_{\mathrm{D}}{ }^{\mathrm{des}} \text { and } \mathrm{HC} \text { of CTC and } \\
\text { metabolites to manure } \mathrm{pH}\end{array}$ & $\begin{array}{l}\text { Effect of } \mathrm{pH} \text { on relative distribution of } \log \mathrm{K}_{\mathrm{D}}^{\mathrm{s}}, \log \mathrm{K}_{\mathrm{D}}{ }^{\mathrm{des}} \\
\text { or } \mathrm{HC} \text { values for CTC and metabolites in manure } \\
\text { samples }\end{array}$ \\
\hline $\begin{array}{l}\text { CTC, ECTC } \\
\mathrm{K}_{\mathrm{D}}^{\mathrm{s}} \text { : Acidic, neutral > weakly-basic }>\text { basic manure } \\
\mathrm{K}_{\mathrm{D}} \text { des: Basic }>>\text { weakly-basic }>\text { acidic, neutral manure } \\
\mathrm{HC} \text { : Acidic, neutral > weakly-basice >> basic manure }\end{array}$ & $\begin{array}{l}\text { Acidic manure } \\
\mathrm{K}_{\mathrm{D}}^{\mathrm{s}}: \quad \text { CTC, ECTC }>\text { ACTC, EACTC }>\text { ICTC, EICTC } \\
\mathrm{K}_{\mathrm{D}}^{\mathrm{des}} \text { : ICTC, EICTC > CTC, ECTC > ACTC, EACTC } \\
\text { HC: CTC, ECTC, ACTC, EACTC > ICTC, EICTC }\end{array}$ \\
\hline $\begin{array}{l}\text { ACTC, EACTC } \\
\mathrm{K}_{\mathrm{D}}^{\mathrm{s}} \text { : Acidic, neutral, weakly-basic > basic manure } \\
\mathrm{K}_{\mathrm{D}}^{\text {des }} \text { : Basic >>acidic, neutral, weakly-basic manure } \\
\mathrm{HC} \text { : Acidic, neutral, weakly-basic > basic manure }\end{array}$ & $\begin{array}{l}\text { Neutral manure } \\
\mathrm{K}_{\mathrm{D}}^{\mathrm{s}} \text { : ACTC, EACTC, CTC, ECTC, ICTC, EICTC } \\
\mathrm{K}_{\mathrm{D}}^{\text {des: }} \text { ICTC, EICTC > ACTC, EACTC > CTC, ECTC } \\
\text { HC: ACTC, EACTC > CTC, ECTC >> ICTC, EICTC }\end{array}$ \\
\hline $\begin{array}{l}\text { ICTC, EICTC } \\
\mathrm{K}_{\mathrm{D}}^{\mathrm{s}} \text { : Acidic, neutral, weakly-basic > basic manure } \\
\mathrm{K}_{\mathrm{D}}^{\mathrm{des}} \text { : Basic > weakly-basic, neutral, acidic manure } \\
\mathrm{HC} \text { : Acidic, neutral, weakly-basic > basic manure }\end{array}$ & $\begin{array}{l}\text { Weakly-basic manure } \\
\mathrm{K}_{\mathrm{D}}^{\mathrm{s}} \text { : ACTC, EACTC > CTC, ECTC, ICTC, EICTC } \\
\mathrm{K}_{\mathrm{D}}^{\mathrm{des}} \text { : ICTC, EICTC > ACTC, EACTC, CTC, ECTC } \\
\text { HC: CTC, EACTC > ACTC, EACTC > ICTC, EICTC }\end{array}$ \\
\hline & $\begin{array}{l}\text { Basic manure } \\
\mathrm{K}_{\mathrm{D}}^{\mathrm{s}}: \text { ACTC, EACTC > CTC, ECTC > ICTC, EICTC } \\
\mathrm{K}_{\mathrm{D}}^{\text {des }} \text { : ICTC, EICTC > ACTC, EACTC, CTC, ECTC } \\
\text { HC: CTC, ECTC > ICTC, EICTC, ACTC, EACTC }\end{array}$ \\
\hline
\end{tabular}

\subsubsection{Tylosin and Metabolites}

LogK ${ }_{D}{ }^{d e s}, \log K_{D}{ }^{s}$ and HC values for TYL-A, TYL-B, TYL-D and TYL-ALD in manure are shown in Figure 11 and the statistical analyses of the data are shown in Figure 12. For acidic and neutral manure, individual $\log \mathrm{K}_{\mathrm{D}}{ }^{\text {des }}$ values were greater than corresponding $\log \mathrm{K}_{\mathrm{D}}{ }^{\mathrm{s}}$ values, indicating sorption-desorption hysteresis. The $\mathrm{HC}$ values ranged from $6 \%$ to $15 \%$ for TYL-D, $25 \%$ to $30 \%$ for TYL-A and TYL-ALD and > 40\% TYL-B. However, $\log \mathrm{K}_{\mathrm{D}}{ }^{\mathrm{des}}$ and $\log \mathrm{K}_{\mathrm{D}}{ }^{\mathrm{s}}$ 


\section{A Macrothink}

values were comparable in basic manure samples, indicating poor or lack of hysteresis. Comparative pattern of $\log \mathrm{K}_{\mathrm{D}}{ }^{\mathrm{s}}, \log \mathrm{K}_{\mathrm{D}}{ }^{\text {des }}$ and $\mathrm{HC}$ values for TYL-A and metabolites in acidic, neutral, weakly basic and basic manure samples are shown in Table-6. In general, except for TYL-D, the $\log \mathrm{K}_{\mathrm{D}}{ }^{\mathrm{s}}$ and HC values for TYL-A, TYL-B and TYL-ALD were lower than corresponding $\log \mathrm{K}_{\mathrm{D}}{ }^{\text {des }}$ values in acidic, neutral and weakly-basic manure samples. As the manure $\mathrm{pH}$ increased to $\geq 9$, the $\log \mathrm{K}_{\mathrm{D}}{ }^{\mathrm{s}}$ and $\mathrm{HC}$ values decreased.
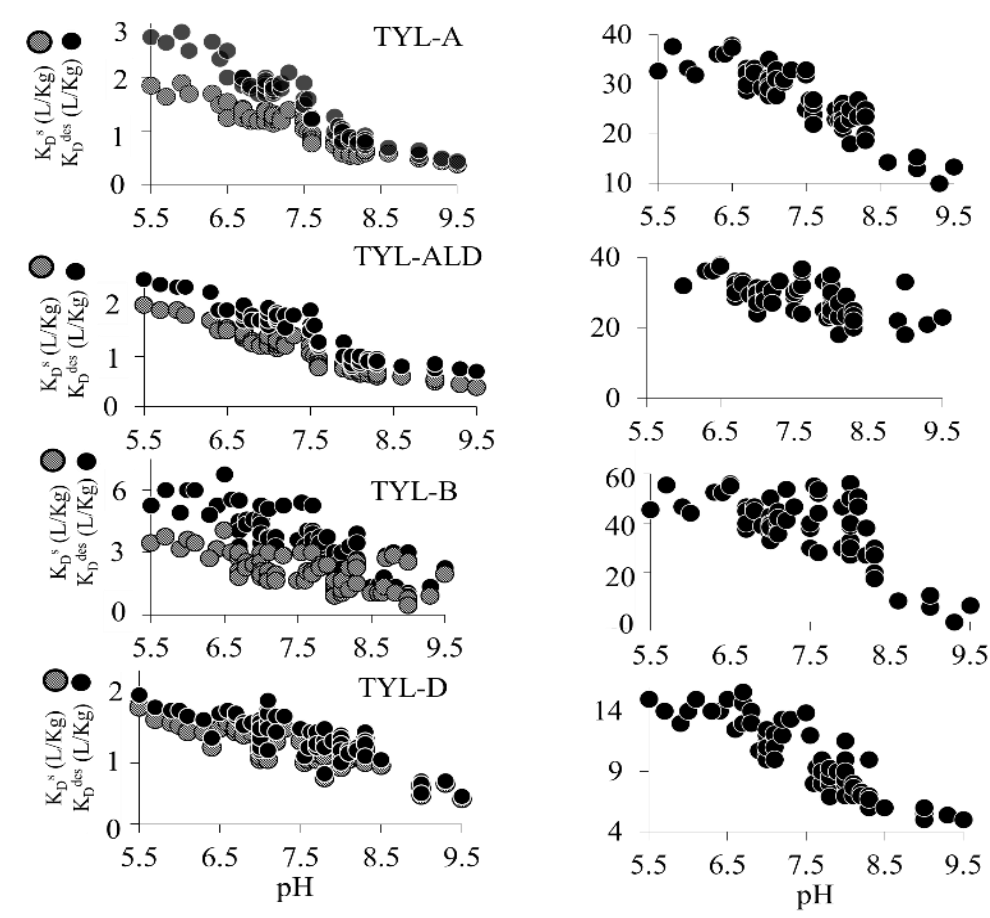

Figure-11. Typical $\mathrm{pH}$ versus $\log \mathrm{K}_{\mathrm{D}}{ }^{\mathrm{s}}$ or $\log \mathrm{K}_{\mathrm{D}}{ }^{\text {des }}$ (11a) and $\mathrm{pH}$ versus HYS (11b) plots for TYL-A and metabolites in manure samples

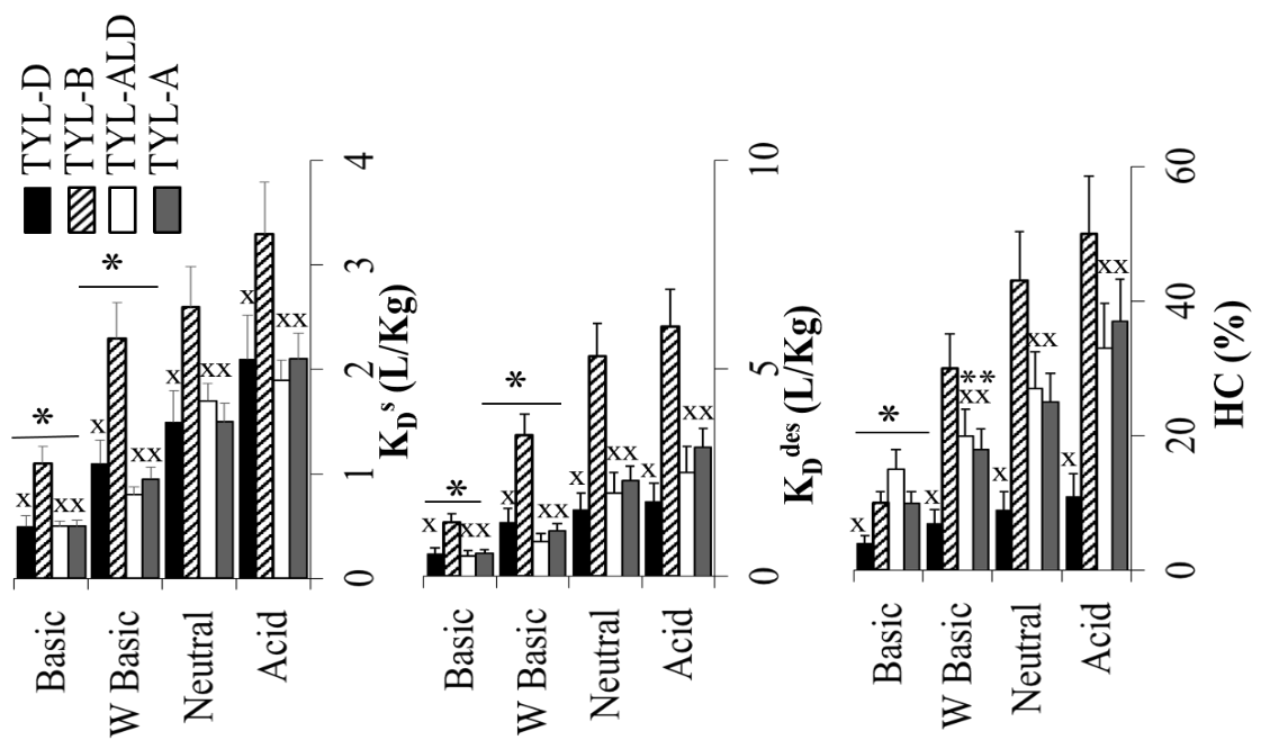

Figure-12. $\log \mathrm{K}_{\mathrm{D}}{ }^{\mathrm{s}}, \log \mathrm{K}_{\mathrm{D}}{ }^{\mathrm{des}}$ and $\mathrm{HC}$ values for TYL-A and metabolites in acidic, neutral, weakly-basic ( $\mathrm{W}$ basic) and basic manure samples. 
Table-6: Effect of manure $\mathrm{pH}$ on sorption, desorption and hysteresis of TYL-A and metabolites.

\begin{tabular}{|c|c|}
\hline $\begin{array}{l}\text { Sensitivity of } \log \mathrm{K}_{\mathrm{D}}^{\mathrm{s}}, \log \mathrm{K}_{\mathrm{D}}^{\text {des }} \text { and } \mathrm{HC} \text { of TYL-A and } \\
\text { metabolites to manure } \mathrm{pH}\end{array}$ & $\begin{array}{l}\text { Effect of } \mathrm{pH} \text { on relative distribution of } \log \mathrm{K}_{\mathrm{D}}^{\mathrm{s}} \text {, } \\
\log \mathrm{K}_{\mathrm{D}}^{\text {des }} \text { or } \mathrm{HC} \text { values TYL-A and metabolites in } \\
\text { manure samples }\end{array}$ \\
\hline $\begin{array}{l}\text { TYL-A, } \\
\mathrm{K}_{\mathrm{D}}^{\mathrm{s}} \text { : acidic, neutral < weakly basic, basic manure } \\
\mathrm{K}_{\mathrm{D}}{ }^{\text {des }} \text { : acidic, neutral < weakly basic, basic manure } \\
\mathrm{HC}: \quad \text { acidic, neutral < weakly basic, basic manure }\end{array}$ & $\begin{array}{l}\text { Acidic } \\
\mathrm{K}_{\mathrm{D}}^{\mathrm{s}}: \quad \text { TYL-B }>\text { TYL-A, TYL-ALD > TYL-D } \\
\mathrm{K}_{\mathrm{D}}^{\mathrm{des}}: \text { TYL-D > TYL-A, TYL-ALD > TYL-B } \\
\text { HC: } \quad \text { TYL-A, TYL-ALD, TYL-B >> TYL-D }\end{array}$ \\
\hline $\begin{array}{l}\text { TYL-B } \\
\mathrm{K}_{\mathrm{D}}^{\mathrm{s}} \text { : acidic, neutral, weakly basic }>\text { basic manure } \\
\mathrm{K}_{\mathrm{D}}{ }^{\text {des }} \text { : acidic, neutral < weakly basic, basic manure } \\
\mathrm{HC}: \text { acidic, neutral, weakly basic, basic manure }\end{array}$ & $\begin{array}{l}\text { Neutral } \\
\mathrm{K}_{\mathrm{D}}^{\mathrm{s}} \text { : } \text { TYL-B > TYL-A, TYL-ALD > TYL-D } \\
\mathrm{K}_{\mathrm{D}} \text { des }: \text { TYL-D > TYL-A, TYL-ALD > TYL-B } \\
\text { HC: } \quad \text { TYL-A, TYL-ALD, TYL-B >> TYL-D }\end{array}$ \\
\hline $\begin{array}{l}\text { TYL-ALD } \\
\mathrm{K}_{\mathrm{D}}^{\mathrm{s}} \text { : acidic, neutral V weakly basic, basic manure } \\
\mathrm{K}_{\mathrm{D}}{ }^{\text {des }} \text { : acidic, neutral < weakly basic }>\text { basic manure } \\
\mathrm{HC}: \quad \text { acidic, neutral }<\text { weakly basic }>\text { basic manure }\end{array}$ & $\begin{array}{l}\text { Weakly basic } \\
\mathrm{K}_{\mathrm{D}}^{\mathrm{s}} \text { : TYL-B }>\text { TYL-A, TYL-ALD > TYL-D } \\
\mathrm{K}_{\mathrm{D}}^{\mathrm{des}} \text { : TYL-D > TYL-A, TYL-ALD > TYL-B } \\
\text { HC: } \quad \text { TYL-B > TYL-A, TYL-ALD >> TYL-D }\end{array}$ \\
\hline $\begin{array}{l}\text { TYL-D } \\
\mathrm{K}_{\mathrm{D}}^{\mathrm{s}} \text { : acidic, neutral < weakly basic }>\text { basic manure } \\
\mathrm{K}_{\mathrm{D}} \text { des: acidic, neutral }<\text { weakly basic }>\text { basic manure } \\
\mathrm{HC}: \text { acidic, neutral < weakly basic }>\text { basic manure }\end{array}$ & $\begin{array}{l}\text { Basic } \\
\mathrm{K}_{\mathrm{D}}^{\mathrm{s}}{ }^{\mathrm{s}} \text { : TYL-A, TYL-ALD, TYL-B, TYL-D } \\
\mathrm{K}_{\mathrm{D}}^{\mathrm{des}} \text { : TYL-D > TYL-A, TYL-ALD > TYL-B } \\
\text { HC: } \quad \text { TYL-A, TYL-ALD, TYL-B >> TYL-D }\end{array}$ \\
\hline
\end{tabular}

\section{Discussion}

\subsection{Physicochemical Properties of Manure}

Manure is a slurry of organic and inorganic matter containing animal feces, urine, soil, water, organic carbon, fatty acids, minerals and other nutrients, drugs and toxins. Manure solid contains particles of varying sizes with a series of negative-charged domains where the charge increases in the following order: organic matter > clay > slit > sand. Since only $10 \%$ to $40 \%$ of the soil's negative charges are $\mathrm{pH}$ dependent, we expect that soil may retain its negativity at $\mathrm{pH}$ ranging from 6 to $>9$ (Christensen et al 2009, Gregory et al 1989). Manure solid would attract positively charged ions, but repel negatively charged ions present in the supernatant. An incomplete charge neutralization may yield net +ve and -ve charges at the surface (Gregory 1973, Vanotti and Hunt 1999, Hjorth et al 2010). Although the point of zero charge (PZC) for pig manure is not yet known, earlier study has proposed it to be at approximately $\mathrm{pH} 4.5$ to 5.5 (Chen et al. 2013 and Trakal et al. 2014), thus manure may contain negative charge at $\mathrm{pH}>6.0$. Total CEC of manure ranges from 50 to $100 \mathrm{meq}$ (Table-1, Jiang 2015) at $\mathrm{pH} 6$ and the values decrease as the $\mathrm{pH}$ increases (Figueroa et al 2004). Based on the above and other relevant observations (Cashen 1959, Wiklander 1964, Barrow and Shaw 1979, Barrow 1985, Galleg et al 1976, Mulder and Cresser 1994, Apple et al 2003, Rengel 2003, Fontes and Alleoni 2006, Sposito 2008, Wegst-Uhrich et al. 2014), it is proposed that the following key ionic properties may determine sorption of an antibiotics on manure solid:

(i) Manure solid may exhibit net negative charge even at acidic $\mathrm{pH}$ that may directly bind the 
$-\mathrm{NH}^{+}\left(\mathrm{CH}_{3}\right)_{2}$ group of TYL-A, CTC or the metabolites..

(ii) Cation exchange capacity (CEC) is highest in acidic manure, and the values decreased as the $\mathrm{pH}$ increased.

(iii) In acidic manure, the carboxylic groups remaind deionized (-COOH) and the basic groups or nutrients remained ionized $\left(\mathrm{Al}^{3+}, \mathrm{Na}^{+}, \mathrm{Ca}^{2+}, \mathrm{K}^{+}, \mathrm{NH}_{4}^{+}\right.$etc). As $\mathrm{pH}$ increased, the ionized/deionized ratio of metals decreased, but the ratio of carboxylic acid increased. Cations such as $\mathrm{Na}^{+}, \mathrm{Ca}^{2+}$ and $\mathrm{NH}_{4}{ }^{+}$may replace the proton from $-\mathrm{COOH}$ and form $-\mathrm{COO}^{-} \mathrm{Na}^{+}$that may be further replaced with cationic antibiotics, a process known as cation exchange.

(iv) Manure solid also contain hydrophobic sites that may interact with the hydrophobic sites of the antibiotics.

\subsection{Physicochemical Properties of Antibiotics}

CTC and its metabolites are polar compounds with $\log \mathrm{P}$ ranging from -0.58 to $-3.37(\log \mathrm{P}$ pattern: ACTC, EACTC (-0.58) > ICTC, ETCTC (-2.17) > CTC, ECTC (-3.37)). They contain strong negative-charged and a weak positive-charged domains, separated by hydrophobic domains (Figure 6). TYL (log P pattern: TYL-B (2.3) > TYL-D (1.69), TYL-A (1.65) > TYL-ALD (1.3)) contains diffused positively charged sites with dispersed hydrophobic regions (Figure-4). CTC, depending on the solvent $\mathrm{pH}$, exhibit complex ionization patterns because of multiple ionizing groups with different $\mathrm{pKa}$ values listed below (Cosentino et al 2005, Stephens et al 1956, Myers et al 1983, Nelson et al 2001 and Wang et al 2014):

- The pKa1for protonation of $\mathrm{N}_{4}\left(\mathrm{CH}_{3}\right)_{2}-\mathrm{C} 4$ ranged from 9.1 to 9.7 for CTC, ECTC, ACTC and EACTC, while the values were 8.1- 8.4 for ICTC and EICTC. In this pH range, the following pattern may exist: cations $(0-0,0--,+--)>$ zwitterion $(+0-)>>$ anion $(+00)$.

- The pKa2 for deprotonation of $\mathrm{O}_{10}-\mathrm{C}_{10}, \mathrm{O}_{11}-\mathrm{C}_{11}$ and $\mathrm{O}_{12}-\mathrm{C}_{12}$ ranged from 7.2 to 7.8 for CTC, ECTC, ACTC and EACTC, while 6.8 ICTC and EICTC. In this $\mathrm{pH}$ range, the following pattern may exist: zwitterion $(+0-)>$ cations $(0-0,0--,+--)>$ anions $(+00)$.

- The $\mathrm{pKa} 3$ for $\mathrm{O}_{3}$ and $-\mathrm{C}_{2}\left(\mathrm{C}_{2 \mathrm{a}}=\mathrm{O}\right) \mathrm{N}_{2 \mathrm{a}} \mathrm{H}_{2}$ were $<5$ for $\mathrm{CTC}$ and its metabolites. In this $\mathrm{pH}$ range, anions (+00) may dominate.

CTC and metabolites, because of slight differences in their pKa values, may exhibit diverse ionic properties and ensuing interactions with manure. However, the pKa values for TYL-A and metabolites were 9.4, thus they may exist an anion $\left(\mathrm{TYL}^{+}\right)$throughout the $\mathrm{pH}$ range of this study.

\subsection{Concentration of CTC, TYL-A and their metabolites in pig manure liquid fraction}

Antibiotics concentrations in manure and other environmental samples are generally determined by ELISA (for screening and determination of positive samples) and/or HPLC-MS (for quantitative determination of positive samples) (Aga et al 2003, Christiana et 
al 2003, Sorensen 2006, Ben et al. 2008, Hu et al. 2010, Shahbazi et al. 2015). An earlier study (Kumar et al. 2004) has shown that analysis of manure samples by ELISA and HPLC-MS yielded different results (concentrations of CTC and TYL were 0 to $7.93 \mathrm{mg} / \mathrm{L}$ and 0 to $5.23 \mathrm{mg} / \mathrm{L}$, respectively, when analyzed by ELISA, but 0 to 5.23 and 0 to $3.8 \mathrm{mg} / \mathrm{L}$, respectively, when analyzed by HPLC-MS), possibly be due to the presence metabolites that may have cross-reacted with the ELISA antibodies, as suggested by other investigators (Hu et al. 2008, Aga et al. 2005). Since many of the metabolites exhibit antibacterial activity and/or nonspecific toxicity (Henderson et al. 2008, Hu et al. 2008, Teeter and Meyerhoff 2003, Dos Santos et al. 2000), presence of active metabolites in manure samples may pose substantial risk of environmental contamination and ensuing risk of public health. Therefore, in the present study, a quantitative/confirmatory method using HPLC/MS-MS that provided clear separation of the antibiotics' and their metabolites was used. The method yielded the following results:

(i) Approximately $36 \%$ of pig manure samples tested positive (in quantitative terms) for CTC, TYL and/or their metabolites. Their concentrations ranged from 0.1 to $>1 \mathrm{mg} / \mathrm{L}$ that were consistent with earlier values reported for the United States, Europe and China (Loke et al. 2002, Winckler and Grafe 2001, Chen et al. 2012, Zhao et al. 2010, Halling-Sorensen et al. 2005, Kumar et al. 2005).

(ii) The TYL-A metabolites were TYL-B, TYL-D and TYL-ALD, while CTC metabolites were ICTC, ACTC, ECTC, EICTC and EACTC.

(iii) The relative concentrations of the metabolites depended upon the manures' $\mathrm{pH}$. The TYL-positive acidic and neutral samples contained mostly TYL-A and TYL-B, while the basic samples contained mostly TYL-D and TYL-ALD. CTC-positive acidic samples contained mostly CTC, ACTC and EACTC, while basic samples contained mostly ICTC and EICTC.

The pH-related changes in concentrations of TYL-A, CTC and metabolites depended on their ionization properties. TYL-A and metabolites are weekly basic in which the $-\mathrm{N}\left(\mathrm{CH}_{3}\right)_{2}$ group may remain protonated throughout the $\mathrm{pH}$ ranging from 5.5 to 9.5 in manure. CTC and metabolites may be a mixture of anions, cations and amphoteric whose proportion may depend upon the manures' $\mathrm{pH}$. This suggests that $\mathrm{pH}$ may affect the fate (sorption, desorption and degradation) of the antibiotics and their metabolites in antibiotics-positive (antibiotics or metabolite concentration $\geq$ QDL) manure samples.

\subsection{Solid-Liquid Partition Coefficient $\left(K_{D}^{s}\right)$ of CTC, TYL-A and Metabolites}

Antibiotics, upon entering manure, distribute between its solid and liquid fractions, a process determined by the parameter $\mathrm{K}_{\mathrm{D}}{ }^{\mathrm{s}}$ (Tills 2001) that depends on (i) the manures' physicochemical characteristics such as particle size, $\mathrm{pH}$, organic carbon, ionic charge, cation-exchange capacity, and (ii) the antibiotics' physicochemical properties such as lipophilicity, ionization status, dipole moment, ion exchange capacity, steric structure and topology (Thiele-Bruhn et al. 2004; Figueroa et al. 2004; Golet et al. 2003; Kulshrestha et al. 2004, Parolo et al. 2008). Manure solid may contain the following binding sites (Loke et al. 
2002, Tolls 2001, Sithole and Guy 1987ab):

(i) hydrophobic sites that may interact with the hydrophobic sites of antibiotics and metabolites,

(ii) cation exchange (CE) sites on which a cationic ion is replaced by another cationic residue,

(iii) cationic $\left(\mathrm{COO}^{-}, \mathrm{SO}_{4}{ }^{2-}, \mathrm{Cl}^{-}\right.$, etc. $)$sites that may bind the positively charged antibiotics such as $\left(\mathrm{CTC}^{+00}\right.$ or TYL-A $\left.{ }^{+}\right)$,

(iv) anionic $\left(\mathrm{Ca}^{2+}, \mathrm{Mg}^{2+}, \mathrm{Na}^{+}, \mathrm{NH}_{4}^{+}\right)$sites that may bind $\mathrm{CTC}^{0--}$ or $\mathrm{CTC}^{0-0}$,

(v) zwitterion (-OOC-X- $\mathrm{NH}_{3}^{+}$) sites that may bind $\mathrm{CTC}^{+0-}$

Earlier studies have shown that sorption of antibiotics on manure solid may occur via diverse mechanisms including, but not limited to, Van der Waals and London dispersion forces, solvent partitioning-hydrophobic interactions, electrostatic attraction-repulsion, ion exchange and H-bonding (Chiou et al. 1989, Xia 1998, Evanko and Dzombak 1998, MacKay and Canterbury 2005, Lertpaitoonpan et al. 2009). TYL-A and its metabolites remain positively charged $\left(-\mathrm{NH}^{+}\left(\mathrm{CH}_{3}\right)_{2}\right)$ at $\mathrm{pH}$ ranging from 5.5 to 9 , while CTC and metabolites exist as a mixture different ions: (i) $+00>+0$ - at $\mathrm{pH} 5.5$ to 6.5 , (ii) $+0->+00>0-0 \mathrm{pH} 6.5$ to 7.5 , (iii) $0-0>+0->0--$ at $\mathrm{pH} 7$ and (iv) 0- - > 0-0 at pH greater than 9. In acidic manure or soils, sorption of $\mathrm{CTC}^{+00}$ and TYL-A ${ }^{+}$occur mostly via cation exchange (Gao and Pedersen 2005, Kahle and Stamm 2007). At $\mathrm{pH}$ range where the zwitterion $\mathrm{CTC}^{+0-}$ dominates, manure exerts a negative effect on antibiotics' sorption (Gao and Pedersen 2005). At pH >9, CTC may exist as an anion and interact with manure's cationic sites via cationic bridging (Nowara et al. 1997; Otker and Akmehmet-Balcioglu, 2005).

$\log \mathrm{K}_{\mathrm{D}}{ }^{\mathrm{s}}$ values for TYL-A, -ALD, -B and -D ranged from $<1.0$ to $4.0 \mathrm{~L} / \mathrm{Kg}$ (Table 4), while, the values for CTC and its metabolites ranged from <1 to 3.0 (Figure 10) that were comparable to the $\log \mathrm{K}_{\mathrm{D}}{ }^{\mathrm{s}}$ values reported by Loke et al. 2002, Wegst-Uhrich et al. 2014, Ingerslev and Halling-Sorensen 2001 and Rabolle and Spliid 2000. This study showed that, in manure at $\mathrm{pH} 5.5$ to 8.5 , the $\log \mathrm{K}_{\mathrm{D}}{ }^{\mathrm{s}}$ values for TYL-B were significantly greater than those for TYL-A, TYL-D and TYL-ALD, while the values were significantly lower in manure at $\mathrm{pH} \geq 9$. Sussman et al (2007) have shown that TYL-B is generated from the hydrolysis of the mycarose ring attached at position 4 of the 16-membered lactone ring of TYL-A, making the metabolite more hydrophobic. Thus, TYL-ALD, TYL-A and TYL-D may be more mobile than TYL-B. Similarly, Wegst-Uhrich et al. (2010) found significant differences in sorption behavior between TYL-A and its hydrolysis product TYL- B, but, contrarily, Sussman et al. (2007) found that (i) TYL-A and -D exhibited similar sorption characteristics and (ii) TYL-A's $\log K_{D}$ values were greater than the TYL-B's $\log K_{D}$ values. The cause for these differences is not yet understood. Studies have shown that the $\log \mathrm{K}_{\mathrm{D}}{ }^{\mathrm{s}}$ values for CTC and TYL-A were inversely related to the manures' $\mathrm{pH}$ values: acidic manure exhibiting relatively higher $\log \mathrm{K}_{\mathrm{D}}{ }^{\mathrm{s}}$ values than basic manure (Ter Laak et al. 2006, Spadotto et al. 2003, Westall et al. 1985, Ali et al. 2013, Sassman and Lee 2005, Loke et al. 2002). The present study yielded similar results for CTC, ECTC, ICTC, ETCTC, TYL-A, TYL-D and TYL-ALD, but not for 
ACTC, EACTC and TYL-B whose $\mathrm{K}_{\mathrm{D}}^{\mathrm{s}}$ values were relatively resistant to $\mathrm{pH}$ changes.

\subsection{Desorption Coefficient and Sorption-Desorption Hysteresis}

Desorption (a process by which a chemical including antibiotics pre-adsorbed onto the manure solid is released into the environment) determines migration and bioavailability of chemicals in terrestrial and aquatic environment (Barriuso et al.1994). It is well established that, for manure, soil and other environmental samples, sorption and desorption of a chemical often do not follow the same path, a process known as sorption-desorption hysteresis (HYS). This occurs when an antibiotics (i) forms permanent bonds (such as covalent bond) with manure's organic matter (Bialk et al. 2005), (ii) competes with coexisting HOCs in soils and sediments ( Rana et al. 2003), (iii) forms surface complex and hydrogen bonding (Xia and Pignatello, 2001; Sander et al. 2006, Tolls 2001, Thiele-Bruh 2003, Hamscher et al. 2004), (iv) is trapped within transient pores formed due to the complex nature of the liquid-phase configuration in unsaturated porous medium that presents hysteresis effects (Dane and Wier et al. 1975, Hillel 1980, O'Kane et al 2004, Poulovassilis 1961, Topp and Miller 1966) and (v) is entrapped in an air pocket which further reduces the water content of newly wetted soil that can accentuate the hysteresis effect (Hillel 1980, O'Kane et al. 2004). Hysteretic adsorption-desorption suggests that sorption of chemicals occur with a limited degree of reversibility depending upon both the physicochemical properties of the molecules and the soils involved (Gao et al. 1998a,b, Gramatica and Di Guardo 2002). An increase in hysteresis, therefore, indicates irreversible sorption and ensuing decrease in leaching and contamination (Gao et al. 1998a, Hong-Gian and Jiang 2010, Xu and Li 2010, Li et al. 2011, 2014). Chen (2012) and Kim et al. (2011) have suggested that the migration of desorbed antibiotics from manure to groundwater is one of the key aspects of the deterioration of groundwater quality and ensuing ecotoxicology. In the proceeding sections, possible significance of the $\log \mathrm{K}_{\mathrm{D}}^{\mathrm{s}}$, $\log \mathrm{K}_{\mathrm{D}}{ }^{\text {des }}$ and $\mathrm{HC}$ values in manure samples and associated health risks have been discussed.

\subsubsection{Tylosin and Metabolites}

$\log \mathrm{K}_{\mathrm{D}}{ }^{\mathrm{s}}, \log \mathrm{K}_{\mathrm{D}}{ }^{\text {des }}$ or $\mathrm{HC}$ values for acidic, neutral and weakly-basic manure samples did not differ significantly, but they were significantly higher than corresponding values for basic manure samples. TYL-B (relatively most lipophilic) exhibited significantly higher HC values than TYL-A, TYL-ALD, TYL-D. Similarly to the present study, Sassman et al. (2007), Qian et al. (2011), Guo et al. (2014), Peng et al. (2014) have also reported sorption-desorption HC of TYL-A and other antibiotics in manure, soil and other environmental samples. A key observation of the present study was that TYL-A, TYL-D and TYL-ALD exhibited $\mathrm{pH}$ dependent hysteresis patterns in manures. At $\mathrm{pH} 5.5$ to 6.5 , the HC values were TYL-B >> TYL-A, -ALD > TYL-D. As $\mathrm{pH}$ increased the HC values decreased, but the decrease for TYL-B were several folds greater than that for TYL-A, -ALD and -D. At $\mathrm{pH} \geq 9, \log \mathrm{K}_{\mathrm{D}}{ }^{\mathrm{s}}$ and $\log \mathrm{K}_{\mathrm{D}}{ }^{\text {des }}$ values were essentially comparable indicating absence of hysteresis. This suggests that, at acidic $\mathrm{pH}$, TYL-B will be essentially immobile, TYL-A and -ALD will be moderately mobile and TYL-D will be freely mobile. At $\mathrm{pH} \geq 9$, all may be relatively freely mobile. Therefore, possibility of groundwater and/or surface waters contamination following field application of manure may range from 'highly likely' to 'not likely' depending upon the 


\section{Macrothink}

manure/soil physicochemical properties.

Possible mechanisms for $\mathrm{pH}$-dependent sorption and desorption of TYL is shown in Figure-13. Since the $-\mathrm{N}\left(\mathrm{CH}_{3}\right)_{2}$ group in TYL remains mostly protonated $\left(\mathrm{TYL}^{+}\right)$below $\mathrm{pH}$, it will bind to manure solid via $\mathrm{CE}$ at broad $\mathrm{pH}$ range. At the manure $\mathrm{pH}>9$, the neutral species of TYL may appear, resulting in a moderate decrease in their sorption. Guo et al. (2014) have shown that hydrophobic interactions may become dominant at relatively higher $\mathrm{pH}$, resulting in an increase in sorption of neutral TYL on manure at $\mathrm{pH} 9$. The $\log \mathrm{K}_{\mathrm{D}}$ values at $\mathrm{pH} 9$ may be attributed to the hydrophobic interactions between manure and TYL-A/metabolites.

\subsubsection{CTC and Metabolites}

CTC and metabolites exhibits a complex ionization patterns, sorption, desorption and hysteresis as shown in Figure-14 and described below:

(i) At pH 5.5 to 6.5: CTC, ECTC, ACTC and EACTC may exist as anions (+00), while manure may exhibit a net -ve charge coupled to an exchangeable anion. At this $\mathrm{pH}$ range, CTC, ECTC, ACTC and EACTC exhibit sorption >> desorption, resulting in greater hysteresis. ICTC and EICTC exhibit comparable desorption and sorption, resulting in poor or no hysteresis. The present observations concur with earlier reports that CTC exhibits considerable sorption-desorption hysteresis in acidic soil (Sassman and Lee 2005, Zhao et al 2011 and Fernandez-Calvino et al 201).

(ii) At $\mathrm{pH}>6.5$ to 7.5: ECTC, ACTC and EACTC may exist as anions > zwitterions, while ICTC and EICTC may exist mostly as zwitterions. Thus, desorption may increase and the $\mathrm{HC}$ values may decrease slightly at this $\mathrm{pH}$ range.

(iii) At $\mathrm{pH}>7.5$ to 8.5: Cation 0-0 becomes prominent moiety followed by the zwitterions. ICTC and EICTC may exhibit more cations than CTC, ECTC, ACTC and EACTC.

(iv) At $\mathrm{pH} \geq 9$ : Cations 0 - - and 0-0 may be the predominant ions at this $\mathrm{pH}$. CTC and the metabolites may exhibit comparable sorption and desorption, indicating lack of hysteresis. 


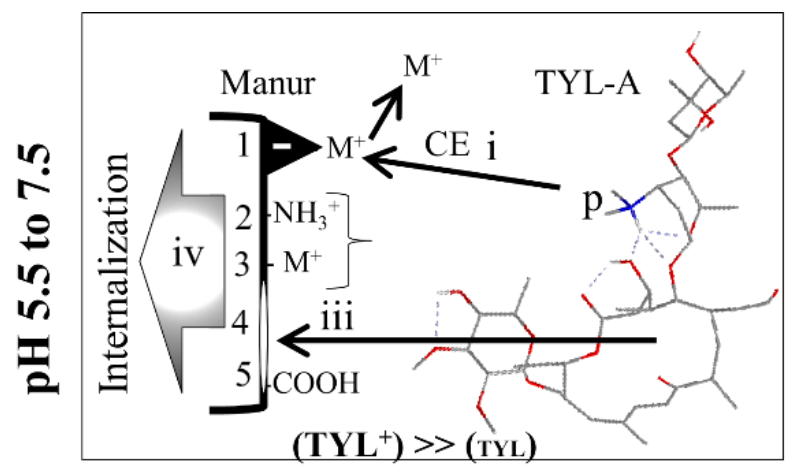

\author{
Sorption \\ TYL-B >> TYL-A, TYL-ALD > TYL-D
}

Desorption

TYL-D > TYL-A, TYL-ALD > TYL-B

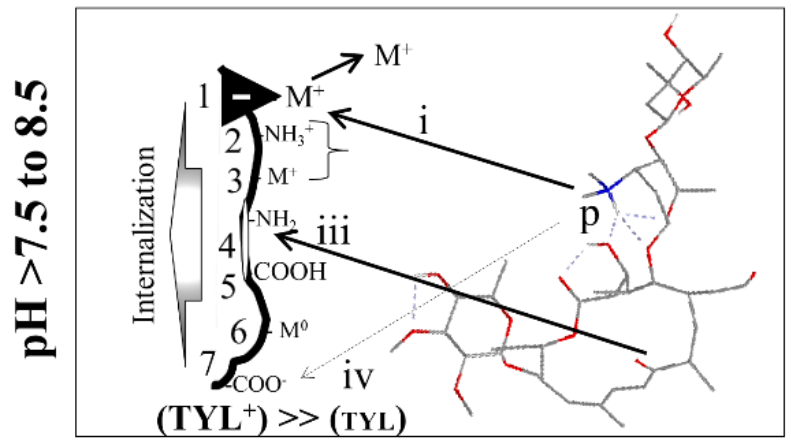

\title{
Sorption
}

TYL-B >> TYL-A, TYL-ALD > TYL-D

Desorption

TYL-D > TYL-A, TYL-ALD > TYL-B

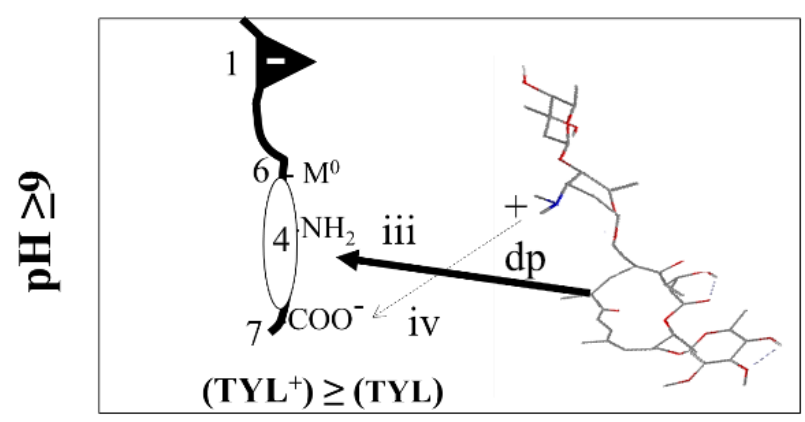

\section{Sorption}

TYL-B, TYL-A, TYL-ALD > TYL-D

\section{Desorption}

TYL-D > TYL-A, TYL-ALD, TYL-B

Figure 13. Proposed mechanisms for sorption and desorption of TYL-A and metabolites in manure.

Abbreviations: (1) Cation exchange sites, (2) ammonium ions, (3) metal ions, (4) hydrophobic sites, (5) protonated (non-ionized) carboxylic group, (6) non-ionized metals ( 0 charge), (7) deprotonated (ionized) carboxylic group, (i) cation exchange between $\mathrm{M}+$ and TYL+ or metabolite+, resulting in sorption of TYL by manure solid at $\mathrm{pH} 5.5$ to 8.5, (ii) hydrophobic interaction between hydrophobic sites of TYL (or metabolites) and manure solid and (iii) a weal interaction between the antibiotic cation and the manure's COO-group.

To understand the complex effects of $\mathrm{pH}$ on desorption of CTC and metabolites from manure solid, it is important to understand the effects of $\mathrm{pH}$ of their physicochemical properties. As discussed above, manure contains (i) organic carbon mostly humic and long-chain fatty acids that accounts for its cationic negative charge, (ii) metal anions that bind the negative charges, (iii) ammonium ions that remains protonated (+ve charge) at acidic $\mathrm{pH}$ and (iv) hydrophilic and hydrophobic sites that interacts with hydrophilic and hydrophobic chemicals, respectively. As shown in Figure 12, at acidic $\mathrm{pH}$, the $-\mathrm{N}(\mathrm{CH} \mathrm{3})_{2}$ group of CTC, ECTC, ACTC and EACTC, because of their lower pKa1, may exhibit greater protonation(and positive charge) than ICTC and EICTC. Therefore, CTC, ECTC, ACTC and EACTC may exhibit lower 
sorption and greater desorption coefficients than ICTC and EICTC.

\section{Conclusions and Environmental Consequences}

As discussed earlier, the domestic livestock industry in the United States produces an estimated 175 million tons of manure each year. The most pragmatic means of disposing manure organic farming by amendment of arable soil with manure where its nutritive value can be utilized by growing plants. In swine intensive-farming, antibiotics are used to treat and prevent disease in swine, to protect swine welfare, and to improve growth rate and efficiency of feed utilization (Mackinnon 1993, Friendship 2000, Cromwell 2002, McEwen and Fedorka-Cray 2002). In the USA, approximately 534 tons of C and 166 tons of TYL are used annually in pig farming (Apley et al. 2012). Since pig manure has been shown to contain 3.5 $\mathrm{mg} / \mathrm{L} \mathrm{TYL}$ and $5.6 \mathrm{mg} / \mathrm{L}$, the total load of these antibiotics in manure may be approximately $5.25 \times 10^{6}$ tons TYL and $8.75 \times 10^{6}$ tons, respectively.
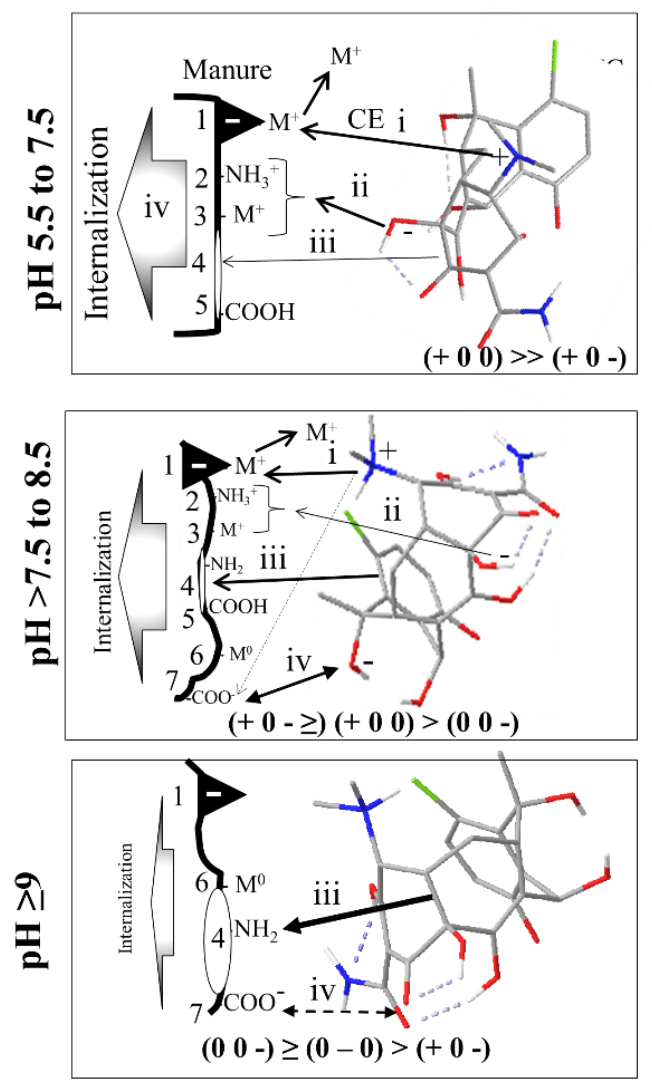

Sorption

ACTC, EACTC $>$ CTC, ECTC $>>$ ICTC, EICTC

Desorption

EICTC, ICTC $\gg$ CTC, ECTC $\gg$ ACTC, EACTC

Sorption

ACTC, EACTC $>$ CTC, ECTC $>>$ ICTC, EICTC

Desorption

EICTC, ICTC $>>$ CTC, ECTC $>>$ ACTC, EACTC

Sorption

ACTC, EACTC, CTC, ECTC $>>$ ICTC, EICTC

Desorption

EICTC, ICTC, CTC, ECTC $>$ ACTC, EACTC

Figure 14. Proposed mechanisms for sorption and desorption of CTC and metabolites in manure.

Abbreviations: ( 1 to 7) described in Figure 13, (i) cation exchange between $\mathrm{M}^{+}$and $\mathrm{CTC}^{+00}$ or metabolite ${ }^{+00}$ at $\mathrm{pH} 5.5$ to 6.5 and, as the $\mathrm{pH}$ increase sorption of CTC and metabolites to soil decrease, (ii) interaction between the anionic domain of CTC and metabolites and the cationic domain of manure, (iii) hydrophobic interaction between hydrophobic sites of CTC (or metabolites) and manure solid and (iv) interaction between the $\mathrm{CTC}$ and metabolite cation and the manure's $\mathrm{COO}^{-}$group. 


\section{Macrothink}

Therefore, during rain event or irrigation, antibiotics from contaminated manure leach to surface water and get carried away to distant sites, creating point and non-point contamination (Dragun 1988). Earlier studies have focused their attention mostly to the parent antibiotics and not to their metabolites that may also exhibit antibiotic properties or nonspecific toxicity. The aim of the present study was compares the scope, sorption and desorption of TYL, CTC and their metabolites in pig manure. The key observation of this study are following:

(1) Approximately $50 \%$ of liquid-phase of pig manure samples contained TYL, CTC and their metabolites, only 36\% contained levels above the method's QDL. The antibiotics and metabolite residue present in the liquid fraction of manure will leach from the storage site directly into the environment. However, the scope of contamination may depend upon its $\mathrm{pH}$ since (i) the acidic TYL-positive manure samples contained TYL-A and TYL-B, while the basic TYL-positive samples contained TYL-A, TYL-ALD and TYL-D, and (ii) the CTC-positive manure samples contained mostly CTC, ECTC and ACTC at acidic pH, but mostly CTC, ICTC, EICTC and EACTC at basic $\mathrm{pH}$. This suggests that the overall environmental impact of contaminated manure may depend upon the medium's $\mathrm{pH}$.

(2) For acidic and neutral manure samples, the $\log \mathrm{K}_{\mathrm{D}}{ }^{\text {des }}$ values for (i) TYL-B, TYL-A and TYL-ALD and (ii) CTC, ACTC, ECTC and EACTC were greater than corresponding $\log \mathrm{K}_{\mathrm{D}}^{\mathrm{s}}$ values, indicating sorption-desorption hysteresis. At this $\mathrm{pH}$, the residues remain manure-bound, thus will not leach and contaminate the environment. However, an increase in $\mathrm{pH}$ decreases hysteresis, resulting in greater leaching and contamination.

(3) TYL-D, ICTC and EICTC did not exhibit sorption-desorption hysteresis, thus the residues will leach on-site due to rain or irrigation.

Thus, once manure is applied to the agricultural field, TYL-A, CTC and their metabolites bound to manure-solid suspended in acidic environment would exhibit poor leaching. However, the rainwater would increase in residues' leaching if the soil is basic. Thus, environmental $\mathrm{pH}$ may determine the antibiotics and metabolite leaching in freshwater at or away from the site of production. In addition, analysis of the parent antibiotic residues may not provide an accurate assessment of the environmental health.

\section{Acknowledgement}

This research was partially funded by a grant from the Graduate School, University of Minnesota. Thanks to S Gupta for technical help.

\section{References}

Aga, D. S., O’Connor, S., Ensley, S., Payero, J. O., Snow, D., \& Tarkalson. D. (2005) Determination of the persistence of tetracycline antibiotics and their degradates in manure-amended soil using enzyme-linked immunosorbent assay and liquid chromatography-mass spectrometry. J. Agric. Food Chem. 53, 7165-7171.

Alcock, R. E., Sweetman, A., \& Jones, K. C. (1999) Assessment of organic contaminant fate 
in wastewater treatment plants I. Selected compounds and physiochemical properties. Chemosphere, 38, 2247-2262.

Ali, M., Wang, J. J., DeLaune, R. D., Seo, D. C., Dodla, S. K., \& Hernandez, A. B. (2013) Effect of redox potential and $\mathrm{pH}$ status on degradation and adsorption behavior of tylosin in dairy lagoon sediment suspension. Chemosphere 91, 1583-1589.

Animal and Plant Health Inspection Service (APHIS). Swine 2006. Part II: Reference of swine health and health management practices in the United States, USDA: Fort Collins, CO, 2006. http:// www.aphis.usda.gov/vs/ceah/ncahs/nahms/swine/swine2006/ Swine 2006 Pt2.pdf .

Apley M.D., Bush E.J., Morrison, R.B., Singer, R.S., Snelson, H. (2012) Use estimates of in-feed antimicrobials in swine production in the United States. Foodborne Pathogens Disease 9, 1-8.

Appel, C., Mab, L.Q., Rhueb, R.D., Kennelleyb, E. (2003) Point of zero charge determination in soils and minerals via traditional methods and detection of electroacoustic mobility. Geoderma 113, 77 - 93.

Aust, M.O., Godlinski, F., Travis, G.R., Hao, X., et al. (2008) Distribution of sulfamethazine, chlortetracycline and tylosin in manure and soil of Canadian feedlots after subtherapeutic use in cattle. Environ. Pollut. 156, 1243-1251.

Barriuso, E., Laird, D.A., Koskinen, W.C. and Dowdy, R.H. (1994) Atrazine desorption from smectites. Soil Sci. Soc. Am. J., 58, 1632-1638.

Barrow, N. J. (1985) Reaction of anions and cations with variablecharge soils. Adv. Agron. 38, 183-230.

Barrow, N. J., Shaw, T.C. (1979) Effect of ionic strength and nature of the cation on desorption of phosphate from soil. J. Soil Sci. 30, 53-65.

Ben, W. W., Qiang, Z. M., Adams. C., et al. (2008) Simultaneous determination of sulfonamides, tetracyclines and tiamulin in swine wastewater by solid-phase extraction and liquid chromatography-mass spectrometry. J Chromatogr A, 1202, 173-180.

Berdy, J. (1985) Screening, classification and identification of microbial products. In Discovery and Isolation of Microbial Products, Ed. Verral MS. Ellis Horwood, Chichester, 9-31.

Berdy, J. (1989) The discovery of new bioactive microbial metabolites: Screening and identification. In Bioactive Metabolites from Microorganisms. Ed. Bushell ME, Grafe U. Elsevier, Amsterdam.

Berdy, J. (1995) Are actinomycetes exhausted as a source of secondary metabolites? In Biotehnologija (ISSN 0234-2758) Proc. 9 ${ }^{\text {th }}$ Int. Symp. On the Biology of Actinomycetes, Moscow. Ed. Debanov VG. 13-34.

Berdy, J., (2005). Bioactive microbial metabolites. J. Antibiotics, 58, 1-26. 
Bialk, H.M.; Simpson, A.J.; Pedersen, J.A. (2005) Cross-coupling of sulfonamide antimicrobial agents with model humic constituents. Environ. Sci. Technol. 39, 4463-4473.

Boxall, A.B., Kolpin, D.W., Halling-Sørensen, B. and Tolls, J. (2003). Peer reviewed: are veterinary medicines causing environmental risks? Environ. Sci. Technol. 37, 286A-294A.

Brady, N.C. (1974) The Nature and Properties of Soil, Macmillan Pub. Co., Inc., New York, 612-621.

Calvet, R. (198). Adsorption of organic chemicals in soils. Environ. Health Perspect. 83, 145-177.

Cashen, G. H. (1959) Electric charges of kaoline. Trans. Faraday Soc. 55, 477-487.

Chee-Sanford, J.C., Aminov, R.I., Krapac, I.J., Garrigues-Jeanjean, N. and Mackie, R.I. (2001) Occurrence and diversity of tetracycline resistance genes in lagoons and groundwater underlying two swine production facilities. Appl. Environ. Microbiol. 67, 1494-1502.

Chen, C., Yang, X., Wei, J., Tan, X., Wang, X. (2013) Eu(III) uptake on rectorite in the presence of humic acid: a macroscopic and spectroscopic study. J Colloid Interface Sci. 393: 249-256.

Chen, Y.; Zhang, H.; Luo, Y.; Song, J. Occurrence and assessment of veterinary antibiotics in swine manures: A case study in east china. Chin. Sci. Bull. 2012, 57, 606-614.

Chiou, C.T., (1989), In reactions and movement of organic chemicals in soils, Soil Society of America: Madison, WI, 1989: 1-30

Christensen, M.L., Hjorth M., Keiding K. (2009) Characterization of pig slurry with reference to flocculation and separation, Water Res. 43, 773-783.

Christiana, T, Schneidera, R. J., Färberb, H. A. et al. (2003) Determination of antibiotic residues in manure, soil and surface waters. Acta Hydrochim Hydrobiol, 31, 36-44

Cosentino, U., Varí, M.R., Saracino, A.A., Pitea, D., Moro, G., Salmona, M. (2005) Tetracycline and its analogues as inhibitors of amyloid fibrils: searching for a geometrical pharmacophore by theoretical investigation of their conformational behavior in aqueous solution. J Mol Model. 11,17-25.

Cromwell, G.L. (2002) Why and how antibiotics are used in swine production. Anim Biotechnol. 13,7-27

Dane, J. H.; P. J. Wierenga, P.J. (1975). Effect of hysteresis on the prediction of infiltration, redistribution and drainage of water in a layered soil. J. Hydrology. 25:229-242.

Demain, A.L. (1999) Pharmacologically active secondary metabolites of microorganisms. Appl. Microbiol. Biotechnol. 52: 455-463 (1999)

Dolliver, H., Kumar, K., Gupta, S. (2007). Sulfamethazine uptake by plants from manure-amended soil. J. Environ. Quality, 36, 1224-1230. 


\section{$\triangle$ Macrothink}

Journal of Agricultural Studies

ISSN 2166-0379

2016, Vol. 4, No. 4

Donadio, S., Monciardini, P., Alduina, R., Mazza, P., Chiocchini, C., Cavaletti, L., Sosio, M., Puglia, A.M. (2002). Microbial technologies for the discovery of novel bioactive metabolites. J. Biotechnol. 99, 187-198.

Dos Santos, H.F., De Almeida, W.B., Zerner, M.C. (1998) Conformational analysis of the anhydrotetracycline molecule: a toxic decomposition product of tetracycline. J. Pharm. Sci. 87, 190-195.

Dragun, J. (1988) The Soil Chemistry of Hazardous Materials, Hazardous Materials Control Institute, Silver Spring, MD, p458.

Elmund, G.K., Morrison, S.M., Grant, D.W., Nevins Sr., M.P. (1971) Role of excreted chlortetracycline in modifying the decomposition process in feedlot waste. Bull. Environ. Toxicol. 6, 129-132.

EPA United States Environmental Protection Agency (2008) Fate, Transport and Transformation Test Guidelines OPPTS 835.1230 Adsorption/Desorption (Batch Equilibrium) EPA 712-C-08-009 October 2008.

EPA United States Environmental Protection Agency (1982). Chemical Fate Test Guidelines; Test Guideline No. CG 1710; Office of pesticides and toxic substances, US Environmental Protective Agency: Washington, DC.

Evanko, C.R., Dzombak, D.A. (1999), Surface complexation modeling of organic acid sorption to goethite. J. Colloid Interface Science. 214, 189-206.

Feinman, S.E., Matheson, J.C. (1978) Draft environmental impact statement: sub-therapeutic antibacterial agents in animal feeds. Food and Drug Administration Department of Health, Education, and Welfare Report, Food and Drug Administration, Washington, DC, p. 372.

Fernandez-Calvino, D., Bermudez-Couso, A., Arias-Estevez, M., Novoa-Munoz, J.C., Fernandez-Sanjurjo, M., Alvarez-Rodríguez, E., Nunez-Delgado, A. (2015) Competitive adsorption/desorption of tetracycline, oxytetracycline and chlortetracycline on two acid soils: Stirred flow chamber experiments. Chemosphere 134, 361-366.

Figueroa, R.A., Leonard, A., Mackay, A.A. (2004) Modeling tetracycline antibiotic sorption to clays. Environ. Sci. Technol. 38, 476-483.

Fontes, M.P.F., Alleoni, L.R.F. (2006) Electrochemical attributes and availability of nutrients, toxic elements, and heavy metals in tropical soils. Sci. Agric. (Piracicaba, Braz.) 63, 589-608,

Friendship, R.M. (2000) Antimicrobial drug use in swine. In: Prescott JF, Baggot JD, Walker $\mathrm{RD}$, eds. Antimicrobial Therapy in Veterinary Medicine. 3rd ed. Iowa State Univ Pr, 602-611.

Gallez, A., A. S. R. Juo, and A. J. Herbillon. (1976) Surface charge characteristics of selected soils in the tropics. Soil Sci. Soc. Am. J. 40, 601-608.

Gao, J.; Pedersen, J.A. (2005). Adsorption of sulfonamide antimicrobial agents to clay-minerals. Environ. Sci. Technol. 39, 9509-9516. 
Golet, E. M., Xifra, I., Siegrist, H., Alder, A. C., Giger, W. (2003). Environmental exposure assessment of fluoroquinolone antibacterial agents from sewage to soil. Environ. Sci. Technol. 37, 3243-3249.

Goni-Urriza, M., Capdepuy, M., Arpin, C., Raymond, N., Caumette, P., Quetin, C., (2000) Impact of an urban effluent on antibiotic resistance of riverine Enterobacteriaceae and Aeromonas spp. Appl. Environ. Microbiol. 66, 125-132.

Gregory J. (1973) Rates of flocculation of latex particles by cationic polymers, J. Colloid Interf. Sci. 42, 448-456.

Gregory, J. (1989) Fundamentals of flocculation, Crit. Rev. Env. Cont. 19, 185-229.

Guo, X., Tu, B., Ge, J., Yang, C., Song, X., Dang, Z. (2016). Sorption of tylosin and sulfamethazine on solid humic acid. J Enviro. Sci. 43, 208-215.

Guo, X., Yang, C., Wu, Y. and Dang, Z. (2014) The influences of pH and ionic strength on the sorption of tylosin on goethite. Environ. Sci. Pollut. Res. 21, 2572-2580.

Habbu, P., Warad, V., Shastri, R., Madagundi, S. and Kulkarni, V.H. (2016) Antimicrobial metabolites from marine microorganisms. Chinese J. Nat. Med. 14, 101-116.

Halling-Sørensen, B. (2001) Inhibition of aerobic growth and nitrification of bacteria in sewage sludge by antibacterial agents. Archives of Environmental Contamination and Toxicology, 40(4), pp.451-460.

Halling-Sorensen, B., Jacobsen, A.M., Sengelov, G., Vaclavik, E. and Ingerslev, F. (2005) Dissipation and Effects of Chlortetracycline and Tylosin in Two Agricultural Soil: A Field-Scale Study in Southern Denmark. Environ. Toxicol. Chem.. 24, 804-810.

Halling-Sorensen, B., Nielsen, S.N., Lanzky, P.F., Ingerslev, F., Lutzhoft, H.C.H., Jorgensen, S.E. (1998). Occurrence, fate, and effects of pharmaceutical substances in the environment-a review. Chemosphere 36, 357-393.

Halling-Sørensen, B., Sengeløv, G. and Tjørnelund, J. (2002). Toxicity of tetracyclines and tetracycline degradation products to environmentally relevant bacteria, including selected tetracycline-resistant bacteria. Arch. Environ. Contam. Toxicol. 42, 263-271.

Hamscher, G., Powelzick, H.T., Höper, H., Nau, H. (2004). Antibiotics in soil routes of entry, environmental concentrations, fate and possible effects. In: Kümmerer, K.(Ed.), Pharmaceuticals in the Environment: Sources, second ed., Fate, Effects and Risks Springer-Verlag, Berlin-Heidelberg, pp. 139-147.

Henderson, K.L., T.B. Moorman, and J.R. Coats. (2008). Mobility of tylosin and enteric bacteria in soil columns. Chapter in Fate of pharmaceuticals in the environment and in water treatment systems. D. Aga [Ed]. CRC Press, Boca Raton, FL.

Hillel, D. (1980). Fundamentals of Soil Physics. Academic Press, New York. pp. 155-161; 457-464. 


\section{MInstitute Macrothink $^{m}$}

Journal of Agricultural Studies

ISSN 2166-0379

2016, Vol. 4, No. 4

Hjorth M, Christensen, K.V., Christensen, M.L., Sommer, S.G. (2010) Solid-liquid separation of animal slurry in theory and practice. A review. Agron. Sustain. Dev. 30, 154 - 176.

Hjorth, M., Christensen, M.L., Christensen, P.V. (2008) Flocculation, coagulation and precipitation of manure affecting three separation techniques, Bioresource Technol. 99, 8598-8604.

Hjorth, M., Christensen, K.V., Christensen, M.L. et al. Agron. Sustain. Dev. (2010) 30: 153.

Hoese, A., Clay, S. A., Clay, D. E., Oswald, J., Trooien, T., Thaler, R., \& Carlson, C. G. (2009). Chlortetracycline and tylosin runoff from soils treated with antimicrobial containing manure. J. Environ. Sci. Health Part B, 44, 371-378.

Hong-Jian, G. A. O. and Jiang, X. (2010) Effect of initial concentration on adsorption-desorption characteristics and desorption hysteresis of hexachlorobenzene in soils. Pedosphere, 20, 104-110.

Hu, X., Zhou, Q., \& Luo, Y. (2010) Occurrence and source analysis of typical veterinary antibiotics in manure, soil, vegetables and groundwater from organic vegetable bases, northern China. Environ. Pollut. 158, 2992-2998

Hu, D., Fulton,B., Henderson, K., \& Coats, J. (2008). Identification of tylosin photoreaction products and comparison of ELISA and HPLC methods for their detection in water. Environ. Sci. Technol. 42, 2982-2987.

Huang, W., Yu, H. \& Weber, W. J. (1998). Hysteresis in the sorption and desorption of hydrophobic organic contaminants by soils and sediments: 1. A comparative analysis of experimental protocols. J. Contam. Hydrol. 31, 129-148.

Ingerslev, F., Halling-Sorensen, B., (2001). Biodegradability of metronidazole, olaquindox, and tylosin and formation of tylosin degradation products in aerobic soil--manure slurries. Ecotoxicol. Environ. Safety 48, 311-320.

Ingerslev, F., Torang, L., Loke, M-L.,Halling-Sorensen, B., Nyholm, N. (2001). Primary biodegradation of veterinary antibiotics in aerobic and anaerobic surface water simulation systems. Chemosphere, 44, 865-872.

Ivanov, P. M. (1998) Molecular Mechanics Conformational Analysis of Tylosin, Ivanov, J. Mol. Struct., 440 (1998) 121-130.

Ivanov PM (2002) CONFLEX/MM3 Search-Minimization Study of the Conformations of the Macrolide Antibiotic Tylosin, PJ. Mol. Struct., 606, 217-229.

Jiang, W.T. (2015) Antibiotic tetracycline in the environments -A review. (2015) J. Pharm. Anal. 4, 86-111.

Kang, D. H., Gupta, S., Rosen, C., Fritz, V., Singh, A., Chander, Y. Rohwer, C. (2013). Antibiotic uptake by vegetable crops from manure-applied soils. J. Agric. Food Chem. 61, 9992-10001. 
Kay, P., Blackwell, P.A. and Boxall, A. (2004). Fate of veterinary antibiotics in a macroporous tile drained clay soil. Environ. Toxicol. Chem. 23, 1136-1144.

Kay, P., Blackwell, P.A. and Boxall, A.B. (2005) Column studies to investigate the fate of veterinary antibiotics in clay soils following slurry application to agricultural land. Chemosphere 60, 497-507.

Kerr, B.J., Ziemer, C.J., Trabue, S.L., Crouse, J.D., Parkin, T.B. (2006) Manure composition of swine as affected by dietary protein and cellulose concentrations. J. Anim. Sci. $84: 1584-1592$.

Kim, K.R., Owens, G., Kwon, S.I., So, K.H., Lee, D.B. and Ok, Y.S. (2011). Occurrence and environmental fate of veterinary antibiotics in the terrestrial environment. Water Air Soil Pollut. 214,163-174.

Klaver, A. L., Matthews, R.A., 1994. Effects of oxytetracycline on nitrification in a model aquatic system. Aquaculture, 123, 237-247.

Kolz, A. C., Moorman, T.B., Ong, S.K., Scoggin, K.D., Douglass, E.A. (2005) Degradation and metabolite production of tylosin in anaerobic and aerobic swine-manure lagoons. Water Environ. Res. 77, 49-56.

Kowalski, Z., Makara, A., Fijorek, K. (2013). Changes in the properties of pig manure slurry. Acta Biochimica. Polonica. 60, 845-850.

Krebs, R., Gupta, S. K., Furrer, G., Schulin, R. (1998). Solubility and plant uptake of metals with and without liming of sludge-amended soils. J. Environ. Qual. 27, 18-23.

Kulshrestha, P., Rossman, F. G., Jr., Aga, D. S. (2004). Investigating the molecular interactions of oxytetracycline in clay and organic matter: Insights on factors affecting its mobility in soil. Environ. Sci. Technol. 38, 4097-4105.

Kumar, K., Gupta S.C., Chander,Y., Singh, A.K. (2005) Antibiotics use in agriculture and its impact on terrestrialenvironment. Advances Agron. 87, 1-54.

Kumar, K., Gupta, S. C., Baidoo, S. K., Chander, Y., \& Rosen, C. J. (2005). Antibiotic uptake by plants from soil fertilized with animal manure. J. Environ. Qual. 34, 2082-2085.

Kumar, K., Thompson, A., Singh, A. K., and Gupta, S. C. (2002). Adsorption of antibiotics on soils. Paper presented at ASA - CSSA - SSSA meeting (November 10-14, 2002), 188. Indianapolis, IN.

Kumar, K., Thompson, A., Singh, A.K., Chander, Y. and Gupta, S.C. (2004). Enzyme-linked immunosorbent assay for ultratrace determination of antibiotics in aqueous samples. $J$. Environ. Qual. 33, 250-256.

Lax A, Roig A, Costa F (1986) A method for determining the cation-exchange capacity of organic materials. Plant Soil 94, 349-355.

Lens P, Hamelers B, Hoitink H, Bidlingmaier W (2004) Resource recovery and reuse in 
organic solid waste management, 249-261. IWA Publishing.

Lertpaitoonpan, W., Ong, S.K., Moorman, T.B. (2009) Effect of organic carbon and pH on soil sorption of sulfamethazine. Chemosphere 76, 558-64.

Lesan, H.M., Bhandari, A. (2003). Atrazine sorption on surface soils: Time-dependent phase distribution and apparent desorption hysteresis. Water Res. 37, 1644-1654

Levy, S.B., (1998) Multidrug resistance- A sign of the times. (1998). New Eng J Med 338, 1376-1378.

Li, Y.W., Wu, X.L., Mo, C.H., Tai, Y.P., Huang, X.P., Xiang, L. (2011) Investigation of sulfonamide, tetracycline, and quinolone antibiotics in vegetable farmland soil in the Pearl River Delta area, southern China. J Agric Food Chem 59:7268-7276.

Li, H., Zhang, D., Han, X. and Xing, B. (2014). Adsorption of antibiotic ciprofloxacin on carbon nanotubes: pH dependence and thermodynamics. Chemosphere 95, 150-155.

Loke, M.L., Jespersen, S., Vreeken,R., Halling-Sørensen,B., Tjørnelund, J. (2003) Determination of oxytetracycline and its degradation products by high-performance liquid chromatography-tandem mass spectrometry in manure-containing anaerobic test systems. $J$. Chromatogr. B, 783, 11-23

Loke, M.L, Tjornelund, J., Halling-Sorensen, B. (2002) Determination of the distribution coefficient $(\log \mathrm{Kd})$ of oxytetracycline, tylosin A, olaquinox, and metronidazole in manure. Chemosphere, 48, 351-361.

MacKay, A.A., Canterbury, B. (2005) Oxytetracycline sorption to organic matter by metal-bridging. J Environ Qual 34, 1964-1971.

MacKay AA, Canterbury B. (2005) Oxytetracycline sorption to organic matter by metal-bridging. J. Environ. Qual. 34, 1964-1971.

Mackinnon, J.D. (1993) The proper use and benefits of veterinary antimicrobial agents in swine practice. Vet Microbiol. 35, 357-367

Martinez-Carballo, E., González-Barreiro, C., Scharf, S., Gans, O. (2007) Environmental monitoring study of selected veterinary antibiotics in animal manure and soils in Austria. Environ Pollut. 148, 570-579.

McCormick, J.R.D., Fox, S.M., Smith, L.L., Bitler, B.A., Reichenthal, J., Origoni, V.E., Muller, W.H., Winterbottom, R. and Doerschuk, A.P. (1957). Studies of the reversible epimerization occurring in the tetracycline family. The preparation, properties and proof of structure of some 4-epi-tetracyclines. J. Am. Chem. Soc. 79, 2849-2858.

McEwen, S. A., Fedorka-Cray, P.J. (2002) Antimicrobial use and resistance in animals. Clin Infect Dis. 34, S93-S106.

Miller, R.W, Donahue, R.L. (1997). Soil Colloids and Chemical Properties, Soils in Our Environment, Prentice-Hall, New York, 127-157. 


\section{MlMacrothink}

Journal of Agricultural Studies

ISSN 2166-0379

2016, Vol. 4, No. 4

Miller, R.W., Donahue, R.L., 1997. Organisms and their Residues. Soils in Our Environment, Prentice-Hall, New York, pp 229-232.

Mulder, J. Cresser, M.S. (1994) Soil and Soil Solution Chemistry. Biogeochemistry of Small Catchments: A Tool for Environmental Research. (Ed) Moldan, B, and Cerny,J., SCOPE, John Wiley \& Sons Ltd.

Myers, H. M., H. J. Tochon-Danguy, and C. A. Baud. (1983). IR absorption spectrophotometry analysis of the complex formed by tetracycline and synthetic hydroxyapatite. Calcif. Tissue Int., 35, 745-749.

Nelson, M. L., W. Hillen, and R. A. Greenwald. (2001). Tetracyclines in biology, chemistry, and medicine. Birkhâuser Verlag. Basel, Boston, Berlin.

Nowara, A., Burhenne, J., Spiteller, M. (1997). Binding of fluoroquinolone carboxylic acid derivatives to clay minerals. J. Agric. Food Chem. 45, 1459-146.

Nozal-Nalda, M. J., Yagüe, B., Luis, J., Gómez, M., Teresa, M., Jiménez Sevilla, J. J. Higes Pascual, M. (2006). Trace analysis of antibacterial tylosin A, B, C and D in honey by liquid chromatography-electrospray ionization - mass spectrometry.J. Separation Sci. 29, 405-413.

O'Kane, J.P., Pokrovskii, A., Flynn D. (2004). The fest model for testing the importance of hysteresis in hydrology. Proc. of EGU conference, 6, 07303.

Ogan, M.T., Nwiika,D.E. (1993). Studies on the ecology of aquatic bacteria of the lower Niger Delta: multiple antibiotic resistance among the standard plate count organisms. J. Appl. Bacteriol. 74, 595-602.

Omura S. (1992) Trends in the search for bioactive microbial metabolites. J Industrial Microbiol 10: 135-156.

Otker, H.M., Akmehmet-Balcioglu, I. (2005). Adsorption and degradation of enrofloxacin, a veterinary antibiotic on natural zeolite. J. Hazard Mater. 122, 251-258

Paesen, J., Cypers, W., Busson, R., Roets, E., Hoogmartens, J. (1995). Isolation and decomposition products of tylosin using liquid chromatograpjy. J. Chromatogr. A. 699, 99-106.

Pan, X., Qiang, Z., Ben, W., Chen, M. 9(011) Residual veterinary antibiotics in swine manure from concentrated animal feeding operations in shandong province, china. Chemosphere 84, 695-700.

Parolo, M. E., Savini, M. C., Vallés, J. M., Baschini, M. T., \& Avena, M. G. (2008). Tetracycline adsorption on montmorillonite: $\mathrm{pH}$ and ionic strength effects. Appl. Clay Sci. 40, 179-186.

Peng, F. J., Zhou, L.J., Ying, G.G., Liu, Y.S. and Zhao, J.L. (2014). Antibacterial activity of the soil - bound antimicrobials oxytetracycline and ofloxacin. Environ. Toxicol. Chem, 33, 776-783. 
Perrier, E.R., Kellogg, M. (1960) Colorimetric determination of soil organic matter. Soil Sci. 90, 104-106.

Peters, J. (2003) Recommended methods for manure analysis. University of Wisconsin, Madison, A3769.

Porubcan, L.S., Serna, C.J., White, J.L. and Hem, S.L. (1978). Mechanism of adsorption of clindamycin and tetracycline by montmorillonite. J. Pharm. Sci. 67, 1081-1087.

Poulovassilis, A. (1961). Hysteresis of pore water: an application of the concept of independent domains. Soil Sci. 93, 405-412.

Powers, W. J., H. H. Van Horn, A. C. Wilkie, C. J. Wilcox, and R. A. Nordstedt. (1999). Effects of anaerobic digestion and additives to effluent or cattle feed on odor and odorant concentrations. J. Anim. Sci. 77:1412-1421.

Qian, Z., Chen, Y., Zhi, D., Weilin H. (2011) Sorption of Tylosin on Agricultural Soils. Soil Sci. 176, 407-412.

Rabolle, M., Spliid, N.H. (2000). Sorption and mobility of metronidazole, olaquindox, oxytetracycline, and tylosin in soil. Chemosphere, 40, 715-722.

Raman, D.R., Williams, E.L, Layton, A.C, Burns, R.T, Easter, J.P, Daugherty, A.S, Mullen, M.D, Sayler, G.S. (2004) Estrogen content of dairy and swine wastes. Environ Sci Technol. 38, 3567-73.

Ran, Y., Xiao, B.; Fu, J.; Sheng, G. (2003) Sorption and desorption hysteresis of organic contaminants by kerogen in a sandy aquifer material. Chemosphere 50, 1365-1376

Rengel Z, (2003) Handbook of soil acidity. New York: Marcel Dekker, Inc.

Sanchez, M., Gonzalez, J.L. (2005) The fertilizer value of pig slurry. I. Values depending on the type of operations. Bioresour. Technol. 96, 1117-1123.

Sanchez-Camazano, M., Gonzalez-Pozuelo, J.M., Sanchez-Martin, M.J., Crisanto, T. (1994). Adsorption and mobility of acephate in soils. Exotoxicol. Exptl. Safety, 29, 61-69.

Sanchez-Camazano, M., Gonzalez-Pozuelo, J.M., Sanchez-Martin, M.J., Crisanto, T. (1994). Adsorption and mobility of acephate in soils. Ecotoxicol. Environ. Safety. 29:61-69.

Sander, M.; Lu, Y.F.; Pignatello, J.J. (2006). Conditioning-annealing studies of natural organic matter solids linking irreversible sorption to irreversible structural expansion. Environ. Sci. Technol. 40, 170-178.

Sassman, S.A. Lee, L.S. (2005) Sorption of Three Tetracyclines by Several Soils: Assessing the Role of $\mathrm{pH}$ and Cation Exchange. Environ. Sci. Technol. 2005, 39, 7452-7459.

Sassman, S.A., Lee, L.S. (2005) Sorption of three tetracyclines by several soils: assessing the role of $\mathrm{pH}$ and cation exchange. Environ Sci Technol, 39, 7452-7459

Sassman, S.A., Sarmah, A.K., Lee, L.S. (2007) Sorption of tylosin A, D, and A-aldol and 
degradation of tylosin a in soils. Environ Toxicol Chem , 26, 1629-1635.

Seybold, C.A., Mersie, W., McName, C., Tierney, D. (1999). Release of atrazine ((14)C) from two undisturbed submerged sediments over a two-year period. J of Agric \& Food Chem $47,2156-2162$

Shahbazi, Y., Ahmadi, F., Karami, N. (2015) Screening, determination and confirmation of tetracycline residues in chicken tissues using fourplate test, ELISA and HPLC-UV methods: comparison between correlation results, Food Agric. Immunol. 26, 821-834.

Simova, S., Ivanov, G. (1996) Proton and Carbon Chemical Shift Assignment and Solution-State Conformation of the Macrocyclic Ring in the Macrolide Antibiotic Tylosin in Aprotic Solvents. Magnetic Resonance Chem. 34, 255-260.

Singh, A.K., Gupta, S., Kumar, K., Gupta, S., Chander, Y., Gupta,A., Saxena, R. (2013) Quantitative analysis of conjugated and free estrogens in swine manure: Solutions to overcome analytical problems due to matrix effects. J. Chromatogr. A, 1305, 203-212.

Singh, A.K. (2015) Aerobic and Anaerobic Transformations in Estrogens and Nutrients in Swine Manure: Environmental Consequences. Agriculture 5, 697-712.

Singh, A.K. (2016) Fate of Conjugated and Free Estrogens in Swine Manure Collected from areas Housing Piglets, Pregnant Sows and Finisher Pigs. J. Agr. Studies. 4: 85-106.

Sithole, B.B., Guy, R.D. (1987a). Models for oxytetracycline in aquatic environments. II. Interaction with humic substances. Water Air Soil Pollut 32, 315-321.

Sithole, B.B., Guy, R.D. (1987b). Models for tetracycline in aquatic environments. Water, Air, Soil Pollut. 32, 303-314.

Soeborg, T., Ingerslev, F., Halling-Sørensen, B. (2004). Chemical stability of chlortetracycline and chlortetracycline degradation products and epimers in soil interstitial water. Chemosphere,

$57,1515-1524$.

Song, W., Guo, M. (2014) Residual Veterinary Pharmaceuticals in Animal Manures and Their Environmental Behaviors in Soils. He Z and Zhang H (eds.), Applied Manure and Nutrient Chemistry for Sustainable Agriculture and Environment, Springer Science Business Media, Dordrecht, 23-52.

Sorensen, B. (2006) Multi-component analysis of tetracyclines, sulfonamides and tylosin in swine manure by liquid chromatography-tandem mass spectrometry. Anal Bioanal Chem, 1164-1174Aust M O, Godlinski F, Travis

Spadotto, C. A., Hornsby, A. G. (2003). Soil sorption of acidic pesticides: modeling pH effects. J. Environ. Qual. 32(3), 949-956.

Sposito, G. (2008) The chemistry of soils.. New York, N.Y.: Oxford University Press.

Stephens, C.R., Murai, K., Brunings, K.J., Woodward, B.R. (1956) Acidity Constants of the Tetracycline Antibiotics. J. Am. Chem. Soc., 78, 4155-4158 


\section{Ml Macrothink}

Journal of Agricultural Studies

ISSN 2166-0379

2016, Vol. 4, No. 4

Sumner, M.E., Miller, P.W. (1996) Cation exchange capacity and exchange coefficients, Methods of Soil Analysis. SSSA and ASA; Madison, 1201-1230.

Teeter JS, R.D. Meyerhoff (2003) Aerobic degradation of tylosin in cattle, chicken, and swine excreta. Environ. Res. 93, 45-51

ter Laak T. L., Gebbink W.A., Tolls J. (2006) Estimation of soil sorption coefficients of veterinary pharmaceuticals from soil properties. Environ. Toxicol. Chem. 25, 933-941

Thiele-Bruhn, S. (2003). Pharmaceutical antibiotic compounds in soils - a review. J. Plant Nutr. Soil Sci. 166, 145-167

Thiele-Bruhn, S., Seibicke, T., Schulten, H. R., \& Leinweber, P. (2004). Sorption of sulfonamide pharmaceutical antibiotics on whole soils and particle-size fractions. J. Environ. Qualm, 33, 1331-1342.

Tolls, J. (2001). Sorption of veterinary pharmaceuticals in soil: A review. Environ. Sci. Technol. 35, 3397-3406.

Topp, G. C., Miller, E.E.. (1966). Hysteresis moisture characteristics and hydraulic conductivities for glass bead media. Soil Sci. Am. Proc. 30, 156-162.

Trakal, L., Šigut, R., Šillerová, H., Faturíková, D. and Komárek, M. (2014). Copper removal from aqueous solution using biochar: effect of chemical activation. Arabian J. Chem. 7, 43-52.

Tylova, T., Fliegera, M., Ol`sovska, J. (2013) Determination of antibiotics in influents and effluents of wastewater-treatment-plants in the Czech Republic - development and application of the SPE and a UHPLC-ToF MS method. Anal. Methods.

USEPA, 2008, Fate, Transport, and Transformation Test Guidelines, Adsorption/Desorption Batch Equilibrium, OPPTS 835.1230.

Vanotti, M.B., Hunt, P.G. (1999) Solids and nutrient removal from flushed swine manure using polyacrylamides, Trans. ASAE 42, 1833- 1840.

Wang, Z-y, Duan,L., Zhu, D-q., Chen, W. (2014) Effects of $\mathrm{Cu}(\mathrm{II})$ and $\mathrm{Ni}(\mathrm{II})$ ions on adsorption of tetracycline to functionalized carbon nanotubes. J. Zhejiang Univ. Sci. A 15, 653-661.

Wegst-Uhrich, S.R., Navarro, D.A.G., Zimmerman, L., Aga, D.S. (2014) Assessing antibiotic sorption in soil: a literature review and new case studies on sulfonamides and macrolides. Chem Cent. J. 8: 5.

Westall, J.C., Leuenberger, C. and Schwarzenbach, R.P. (1985) Influence of pH and ionic strength on the aqueous-nonaqueous distribution of chlorinated phenols. Environ. Sci. Technol. 19, 193-198.

Wiklander, L. (1964). Cation and anion exchange phenomena, In Bear F.E. (ed.) Chemistry of the soil. Reinhold Publishing Corp., New York. 163-205. 


\section{Macrothink}

Journal of Agricultural Studies

ISSN 2166-0379

2016, Vol. 4, No. 4

Winckler, C., Grafe, A. (2001). Use of veterinary drugs in intensive animal production facilities evidence of persistence of tetracycline in pig slurry. J. Soils Sediments 1, 66.

Xia, G.S.; Pignatello, J. J. (2001). Detailed sorption isotherms of polar and apolar compounds in a high-organic soil. Environ. Sci. Technol. 35, 84-94.

$\mathrm{Xu}, \mathrm{X} . \mathrm{R}$. and Li, X.Y., 2010. Sorption and desorption of antibiotic tetracycline on marine sediments. Chemosphere, 78, 430-436.

Zhang, Q., Yang, C., Dang, Z. and Huang, W. (2011) Sorption of tylosin on agricultural soils. Soil Science, 176, 407-412.

Zhao, Y., Geng, J., Wang, X., Gu, X., Gao, S. (2011) Tetracycline adsorption on kaolinite: pH, metal cations and humic acid effects. Ecotoxicology, 20, 1141-1147.

Zhu, J., Snow, D.D., Cassada, D.A., Monson, S.J., Spalding, R.F. (2001). Analysis of oxytetracycline, tetracycline, and chlorotetracycline in water using solid-phase extraction and liquid chromatofraphy-tandem mass spectrometry. J. Chromatogr. A. 928, 177-186.

\section{Copyright Disclaimer}

Copyright for this article is retained by the author(s), with first publication rights granted to the journal.

This is an open-access article distributed under the terms and conditions of the Creative Commons Attribution license (http://creativecommons.org/licenses/by/3.0/). 